\title{
EL BIEN JURÍDICO PROTEGIDO EN EL DELITO DE ABANDONO Y ACTOS DE CRUELDAD CONTRA ANIMALES VERTEBRADOS DOMÉSTICOS Y SILVESTRES MANTENIDOS EN CAUTIVERIO (ARTÍCULO 206 A) EN EL CÓDIGO PENAL PERUANO
}

\author{
THE LEGALLY PROTECTED RIGHT OF THE CRIME OF ABANDONMENT AND ACTS \\ OF CRUELTY TO DOMESTIC AND WILD VERTEBRATE ANIMALS HELD IN CAPTIVITY \\ (ARTICLE 206A) IN THE PERUVIAN CRIMINAL CODE
}

\author{
Beatriz Franciskovic Ingunza ${ }^{1}$ \\ Universidad Femenina del Sagrado Corazón-UNIFÉ \\ Lima-Perú \\ https://orcid.org/0000-0002-5077-2661 \\ beatrizfranciskovici@unife.edu.pe
}

\section{RESUMEN}

Por medio de este comentario se analizará cuál es el bien jurídico protegido del delito de abandono y actos de crueldad contra los animales regulado en el artículo 206 apartado A del Código Penal peruano. Previamente, para mejor comprender, se debe precisar determinados conceptos previos como: qué se entiende por la expresión animal, a qué animales se hace referencia, quién es el sujeto activo y pasivo de este delito incorporado recién en nuestro ordenamiento el año 2016 por la Ley de Protección y Bienestar Animal. Concluyéndose, que el artículo 206 A del Código Penal debe referirse a los animales de compañía y no a todos los vertebrados domésticos.

\section{PALABRAS CLAVES}

Delito de abandono y crueldad animal, animales, sujeto activo, sujeto pasivo, animales de compañía

\begin{abstract}
The purpose of this paper is to identify and analyze the legally protected right or interest of the crime of abandonment and acts of cruelty to animals governed by article 206 section A of the Peruvian Criminal Code. In order to better understand this, certain concepts must be clarified first, such as: what does the term animal mean, what animals are included, who is the perpetrator and who is the victim of this crime. This crime was introduced into our legal system only in 2016 with the passing of the Law on Animal Protection and Welfare. Overall, we conclude that article $206 \mathrm{~A}$ of the Criminal Code must refer to companion animals and not to all domestic vertebrates.
\end{abstract}

\section{KEYWORDS}

Crime of abandonment and animal cruelty, animals, perpetrator, victims, companion animals

1 Abogada y Magister en Derecho Civil de la Universidad San Martín de Porres. Doctoranda en Derecho por la UNMSM. Con estudios de Maestría en Derecho Procesal en la Pontificia Universidad Católica del Perú. Conciliadora Extrajudicial y Árbitro adscrita a la Cámara de Comercio de Lima CCL, CEAR del Colegio de Abogados de Lima CAL, Ministerio de Justicia. Arbitra Perú. Docente Universitaria de la Universidad Esan, Científica del Sur y UNIFÉ. 


\section{INTRODUCCIÓN}

Se analizará cuál es el bien jurídico protegido, el sujeto activo y sujeto pasivo del delito de abandono y actos de crueldad contra los animales vertebrados domésticos y silvestres mantenidos en cautiverio tipificado en el artículo 206 A del Código Penal. Artículo que fue incorporado por la Ley de Protección y Bienestar Animal (Ley 30407 - enero 2016).

Para mejor comprender la temática planteada se empezará por precisar cuál es la situación de los animales en el Derecho comparado como en nuestro ordenamiento, la regulación de la Ley de protección y bienestar animal, sus antecedentes para posteriormente determinar cuál es el bien protegido por dicho delito, el sujeto activo y el sujeto pasivo en nuestro país analizando algunas sentencias relacionadas con ese delito.

\section{LA REGULACIÓN DE LOS ANIMALES POR EL DERECHO LOS ANIMALES EN EL DERECHO COMPARADO}

Para introducirse en la temática o causa animal es necesario partir por señalar qué significa la expresión animal. Animal según el Diccionario de la Real Academia de la Lengua deriva del "latín animal - alis y significa: ser orgánico que vive, siente y se mueve por propio impulso".

Según el Diccionario de Biología: el animal es un organismo pluricelular, capaz de reproducirse y moverse, sin pared celular, que no puede fabricar su propio alimento. [...] Están caracterizados por una incapacidad para fabricar su propio alimento, con lo que necesitan alimentarse de otros organismos o de materia orgánica. Por eso, los animales, son típicamente, formas móviles (para ir a buscar el alimento), y tienen órganos de los sentidos muy desarrollados, para detectar cambios en el medio ambiente. El sistema nervioso coordina la información recibida por los órganos de los sentidos, y determina las respuestas a los estímulos medioambientales. Las células animales no tienen la capa celulosa de las células vegetales. (Diccionario de Biología, 1998, pág. 37)

Las características de todo animal, son las siguientes: es un ser orgánico, un ser vivo, es un ser dotado de sensibilidad perceptible, responde a estímulos externos debido a sus células nerviosas o a su tejido muscular, posee movilidad, es multicelular o pluricelular, es decir, sus células carecen de pared celular. Es Heterótrofo: no puede fabricar su propio alimento. Se alimenta de otros organismos o materia orgánica, y posee capacidad de reproducirse.

Por otro lado, la expresión animal es amplia, es decir, comprende a todas las especies de animales que existen, a la gran cantidad de diversidad de animales. Abarca a los invertebrados, así como a los vertebrados y dentro de los vertebrados a los anfibios (renacuajo, rana) reptiles (serpiente, tortuga, cocodrilo) peces (tiburón, y otros) aves (avestruz, gallina, palomas) mamíferos (delfín, domésticos, de compañía). El Derecho, en principio, se debe ocupar de todos ellos por igual.

Comprendiendo está diversidad de clases de animales, es entendible que el Derecho se refiere a todos ellos de manera general, sin individualizarlos o diferenciarlos. Tratarlos de manera aislada escapa de la seriedad que merece el presente comentario.

Es así que los animales en general, desde la antigüedad hasta la actualidad, han sido y siguen siendo considerados, en la gran mayoría de los países del mundo, como simples bienes muebles por la capacidad que tienen de desplazarse por sí mismos de un lugar a otro. Se les denomina 
semovientes. Son considerados objetos del Derecho, es así que se los asemeja a una cosa material e inerte, sin vida.

Por ello, al ser catalogados como simples bienes muebles, el ser humano puede hacer con ellos, lo que mejor le parezca. Puede hacer uso de todos los atributos que el ordenamiento jurídico concede a todo titular del derecho de propiedad: puede usarlos, aprovecharse de ellos económicamente, disponer de ellos, etc., y de ser el caso reivindicarlos. Lo que también implica que pueda usarlos en investigaciones científicas, como medio de transporte, explotarlos, consumirlos y hacer uso de su piel y, obtener de ellos utilidad y provecho económico.

Sin embargo, a nivel mundial, la regulación de los animales, viene transformándose. Existe la tendencia mundial a la descosificación de los animales, es decir, a ya no considerarlos como simples bienes muebles.

Por ejemplo, desde el año 1974 la Unión Europea ha regulado diversas áreas en las que se utilizan animales en la agricultura, el transporte, para el sacrificio o experimentación. "Esta normatividad ha plasmado el Derecho de los Estados miembros en el ámbito del bienestar animal ${ }^{2}$ mediante reglamentos, que son directamente aplicables, o mediante directivas, que deben transponerse al Derecho estatal". (Giménez-Candela; Cersosimo, 2021, p. 33). Es así que, desde que entró en vigencia en la Unión Europea el Tratado de Funcionamiento de la Unión Europea, después de varias modificaciones al Tratado de Lisboa , 2007 - Tratado de Maastricht sobre la Unión Europa, 1992, en el artículo 13 se establece que "al formular y aplicar las políticas de la Unión en materia de agricultura, pesca, transporte, mercado interior, investigación y desarrollo tecnológico y espacio, la Unión y los Estados miembros tendrán plenamente en cuenta las exigencias en materia de bienestar de los animales como seres sensibles" ${ }^{3}$, respetando al mismo tiempo las disposiciones legales o administrativas y las costumbres de los Estados miembros relativas, en particular, a ritos religiosos, tradiciones culturales y patrimonio regional" (García, 2018)

También es importante señalar que las Constituciones de Austria, Suiza, Alemania, Eslovenia y Luxemburgo como las de Ecuador, Brasil, Bolivia como la nueva Constitución de la Ciudad México prescriben expresamente la protección a los animales. Paralelamente, varios países del mundo han modificado sus ordenamientos jurídicos civiles (Código Civil de Austria, Suiza, Alemania, Republica Checa, Nueva Zelanda, Francia, Portugal) señalando expresamente que los animales no son cosas, son seres vivos dotados de sensibilidad. Sin señalar expresamente qué son.

Sin duda, se advierte la gran transformación y reconocimiento que se está dando a los animales. Tarea que debe continuar, pues, el ser humano debe comprender el buen trato y protección que se les debe otorgar a los animales.

\section{LA REGULACIÓN DE LOS ANIMALES POR EL PERÚ}

Al respecto se puede afirmar que ninguna de nuestras Constituciones Políticas de 1933 y 1979 se refieren a la protección de los animales de manera expresa. La Constitución vigente, en el artículo 68 establece textualmente que el "Estado está obligado a promover la conservación de la diversidad biológica y de las áreas naturales protegidas".

2 El subrayado es nuestro

3 El subrayado es nuestro 
Se podría afirmar que, nuestra Constitución de alguna manera promueve la conservación de los animales, que, aunque, no es lo mismo que protección, por lo menos dispone la obligación que tiene el Estado de promover la conservación de la diversidad biológica, entendiéndose, por diversidad biológica a la gran variedad de animales; sin embargo, el Tribunal Constitucional debido a la demanda de inconstitucionalidad presentada en marzo del año 2019 por una asociación de animalistas; quienes solicitaron que la excepción de la aplicación de la Ley 30407, que excluye de su protección y bienestar a la corrida de toros, pelea de gallos, pelea de toros y otras actividades declaradas culturales, sea declarada inconstitucional; el Tribunal Constitucional, al momento de resolver dicha causa, entre algunos de los considerandos de tres de sus magistrados señalaron que la expresión diversidad biológica sí alcanzaba la protección a los animales, mientras que, para los cuatro magistrados restantes, nuestra Constitución no protegía expresamente a los animales. Razón por lo que la demanda fue declarada infunda. Interpretación cuestionada, pues, al prescribirse la obligación de promover la diversidad biológica, bien podría comprenderse que sí se los quiere proteger de alguna manera.

Sin embargo, y como lo señala el mismo Tribunal Constitucional (2020), a pesar a ello, no se puede dejar de reconocer que nuestro ordenamiento jurídico no ha sido ajeno a la protección y bienestar que se le quiere otorgar a los animales, al considerarlos como seres sensibles, pues, desde la promulgación de la Ley 30407 (enero del año 2016) se prescribe textualmente que los animales tienen condición de seres sensibles. Está ley, solo se refiere a los animales vertebrados domésticos y silvestres mantenidos de cautiverios. La ley se aplica solo a esa clase de animales.

Para lograr una mejor protección y bienestar hacia los animales, sería mejor, importante y necesario que el ordenamiento jurídico civil los reconozca expresamente como no bienes muebles y que la misma Constitución disponga su protección legal.

\section{DIFERENCIA DE LOS ANIMALES DOMÉSTICOS CON LOS DE COMPAÑÍA}

Para abordar el tema que nos convoca es imperioso diferenciar a los animales vertebrados domésticos de los animales de compañía. Está diferencia es imprescindible pues, animales lo son todos en general y no solo los vertebrados domésticos, así como animal doméstico no es sinónimo de compañía.

Se precisa esto, para proceder a determinar ¿a qué animales se quiere proteger, qué animales deben ser considerados como seres sensibles? ¿Todos o solo algunos? ¿Y cuáles en especial?

Sí la respuesta es, a todos los animales por igual sin diferenciación alguna, sin duda, la consecuencia lógica sería que nadie los consuma o los utilice, por ejemplo.

Sí, por el contrario, la respuesta es, solo a determinados animales, la siguiente pregunta sería: ¿a cuáles sí y a cuáles no?

Por lo expuesto, se considera pertinente precisar las diferencias que existen entre los animales domésticos con los animales de compañía. Animal vertebrado doméstico es aquel que tiene columna vertebral, qué vive y cría con el ser humano, el ser humano lo alimenta, lo cuida, lo cobija y obtiene algún beneficio económico, obtiene una utilidad económica. Le proporciona productos y servicios. Son aquellos animales que han sido domesticados para rendir servicio al ser humano. Se encuentran al servicio, dominio y vigilancia de sus dueños y le generan utilidad económica y, o industrial a través de sus productos. Sería un contrasentido abogar por los animales domésticos y al mismo tiempo consumirlos o aprovecharse de ellos. 
El animal de compañía: es un animal doméstico, pero que vive con el ser humano en su hogar, está destinado a la compañía del ser humano. El ser humano lo alimenta, le da cobijo, vive y convive con él, lo considera como parte integrante de su hogar, parte de su familia, y por ende no debe obtener de ellos ninguna utilidad ni beneficio económico, no debe aprovecharse económicamente de él, haciéndole procrear de manera continua para obtener lucro con la venta de sus crías ni venderlos de manera ilegal. Dentro de estos animales se incluyen a los animales que acompañan, conducen y ayudan a personas con discapacidad visual.

Todo animal de compañía es un animal doméstico, pero, no todo animal doméstico es de compañía.

Según nuestro código penal, ¿el delito de abandono y actos de crueldad a qué animales abarca? Posteriormente se dará respuesta a esta interrogante.

\section{ANÁLISIS DEL ARTÍCULO DE ABANDONO Y ACTOS DE CRUELDAD DE LOS ANIMALES VERTEBARDOS DOMÉSTICOS Y SILVESTRES MANTENIDOS EN CAUTIVERIO EN EL CÓDIGO PENAL}

El artículo 206 A del Código Penal, dispone textualmente:

Abandono y actos de crueldad contra animales domésticos y silvestres: El que comete actos de crueldad contra un animal doméstico o un animal silvestre, o los abandona, es reprimido con pena privativa de libertad no mayor de tres años, con cien a ciento ochenta días-multa y con inhabilitación de conformidad con el numeral 13 del artículo 36.

Si como consecuencia de estos actos de crueldad o del abandono el animal doméstico o silvestre muere, la pena es privativa de libertad no menor de tres ni mayor de cinco años, con ciento cincuenta a trescientos sesenta días multa y con inhabilitación de conformidad con el numeral 13 del artículo 36

El artículo en mención tipifica como delito los actos de crueldad contra los animales vertebrados domésticos y silvestres mantenidos en cautiverio y si como consecuencia de ello, se les provoca la muerte, es decir, todos aquellos actos de crueldad contra la vaca, el pavo, el pollo, la gallina, el cerdo y etc. así como contra los silvestres mantenidos en cautiverio.

Y surge la inquietud: ¿quién denuncia algún acto de crueldad contra el animal doméstico o cuándo por estos actos se les causa la muerte? ¿Alguien denuncia realmente algún acto de crueldad producido contra la vaca o cuando a esta se le provoca la muerte para el consumo humano, por ejemplo; máxime cuando el uso del faenado de animales de abasto se encuentra reglamentado ${ }^{4}$.

Sí uno denunciaría estos actos de crueldad contra los animales domésticos, nadie debería, en principio, ni consumirlos ni utilizarlos. O podríamos considerar acaso que la finalidad de este delito ha sido que nadie en el Perú consuma algún animal vertebrado y, por ende, ¿todo el Perú sea vegano?

Al margen de dichas interrogantes, que serán contestadas posteriormente, lo que resulta ser cierto, real y evidente es que nuestra sociedad se está sensibilizando en lo que respecta a la

4 Decreto Supremo N015-2012-AG. Aprueban el Reglamento Sanitario del Faenado de Animales de Abasto 
protección de determinados animales, específicamente, de los animales de compañía, en principio, los perros y gatos o sobre aquellos animales que los seres humanos les tenga un gran afecto y, en consecuencia, no deba consumirlos ni utilizarlos.

Es una realidad que viene creciendo la sensibilización por los animales de compañía por ser los más cercanos a uno, quienes forman parte integrante de las familias, muchas personas los consideran como parte integrante de su hogar, los cuidan, proteger, vigilan y denuncian cualquier acto de crueldad contra ellos. Sin embargo, el tipo penal en mención se refiere a los vertebrados domésticos, es decir, a aquellos que la mayoría de seres humanos consume y, obtiene de ellos algún beneficio o utilidad económica.

Por ello, se considera que este delito se viene aplicando únicamente para el abandono y actos de crueldad cometido contra los animales de compañía. Punto que también será posteriormente explicado.

\section{ANTECEDENTES DE LA REGULACIÓN DEL DELITO DE ABANDONO Y ACTOS DE CRUELDAD DE MALTRATO ANIMAL}

Es importante precisar que antes de la vigente Ley 30407, existía la Ley 27265 Ley de Protección a los animales domésticos y a los animales silvestres mantenidos en cautiverio (19 de mayo 2000) derogada por la actual Ley 30407 Ley de Protección y Bienestar Animal. Esta ley derogada, incorporó en la segunda disposición final y transitoria, como falta, el artículo $450 \mathrm{~A}$ al código penal, regulando como falta los actos de crueldad contra los animales. Textualmente establecía: "el que comete actos de crueldad contra un animal, lo somete a trabajos manifiestamente excesivos o los maltrata, será sancionado hasta con sesenta días multa".

Posteriormente, dicha disposición fue derogada por la Ley 30407 Ley de Protección y Bienestar Animal. Es así que el 09 de enero del año 2016 entró en vigencia dicha Ley, la misma que en su segunda disposición complementaria modificatoria incorporó el apartado A al artículo 206 del Código Penal ${ }^{5}$ tipificando como delito el abandono y actos de crueldad contra animales domésticos y silvestres.

Al respecto y antes de precisar cuál es el bien jurídico protegido en este delito resulta necesario hacer algunas precisiones:

La citada ley solo es aplicable a los animales vertebrados domésticos y silvestres mantenidos en cautiverio, es decir, no se aplica para todos los animales en general.

El artículo 14 de dicha ley expresamente señala que "Para fines de aplicación de la presente ley se reconoce como animales en condición de seres sensibles a toda especie de animales vertebrados, domésticos y silvestres mantenidos en cautiverio"6.

5 SEGUNDA. Incorporación del artículo 206-A al Código Penal Incorpórese el artículo 206-A al Código Penal en los siguientes términos: "Artículo 206-A. Abandono y actos de crueldad contra animales domésticos y silvestres El que comete actos de crueldad contra un animal doméstico o un animal silvestre, o los abandona, es reprimido con pena privativa de libertad no mayor de tres años, con cien a ciento ochenta días-multa y con inhabilitación de conformidad con el numeral 13 del artículo 36. Si como consecuencia de estos actos de crueldad o del abandono el animal doméstico o silvestre muere, la pena es privativa de libertad no menor de tres ni mayor de cinco años, con ciento cincuenta a trescientos sesenta días multa y con inhabilitación de conformidad con el numeral 13 del artículo 36"

6 El subrayado es nuestro. 
Asimismo, La citada ley establece obligaciones y prohibiciones para los dueños, poseedores y tenedores de estos animales, estableciendo sanciones administrativas en caso de incumplimiento, así como por realizar actos de maltrato animal contra dichos animales. Al parecer, como señala Jaurrieta (2019), el Derecho Administrativo en cierto sentido ha fracasado o es que el ser humano no acciona o desconoce lo ahí establecido, razón por la que también se regula el delito de abandono y actos de crueldad contra los animales domésticos y silvestres por el Código penal.

\section{EL BIEN JURÍDICO PROTEGIDO, EL SUJETO ACTIVO Y PASIVO EN EL DELITO DE ABANDONO Y ACTOS DE CRUELDAD CONTRA LOS ANIMALES DOMÉSTICOS Y SILVESTRES}

Después de lo descrito, teniendo en cuenta que el Código Civil peruano, así como el Código Penal sigue considerado y regulando a los animales como bienes muebles (este delito se encuentra ubicado dentro de los delitos contra el patrimonio), ¿cuál sería el bien protegido de este delito?

¿Qué se entiende por bien jurídico protegido?

El bien jurídico, como Von Liszt dijo, es el interés protegido por el Derecho. Pero la polémica, sobre si debe entenderse subjetiva u objetivamente, llega hasta estos días. En la primera tendencia Rocco afirma que el interés es la valoración que un individuo hace de un bien por ser apto para satisfacer una de sus necesidades; cuya valoración puede hacerse mejor en orden a un sujeto determinado. En cambio, Carnelutti, Antolisei y otros autores, ven el interés en la situación de un bien respecto a un individuo, que puede disponer de él para satisfacer sus necesidades. Textualmente dice Carnelutti: posición favorable a la satisfacción de una necesidad. (Jiménez de Asúa, 1965, p. 107-108)

\section{Según Roxin (1997)}

"se caracteriza el bien jurídico como "bien vital" reconocido socialmente como valioso, como "valor jurídico" o "interés jurídico", como interés jurídicamente reconocido "en un determinado bien como tal en su manifestación general", como "la pretensión de respeto emanada de supuestos de hecho valiosos, en la medida en que los órganos estatales han de reaccionar con consecuencias jurídicas ante su lesión no permitida", o como "unidad funcional valiosa" (70)

Respecto al delito de maltrato animal existen varias posiciones respecto a cuál es el bien jurídico protegido. Siguiendo a Jaurrieta podemos resumir las siguientes corrientes:

a. Una corriente, considera que lo que se pretende proteger es la ética y moral existente entre las relaciones de los animales y los hombres, teniendo especial consideración en la dependencia que sufren los primeros respecto de los segundos.

b. Otra, señala que el bien protegido son las obligaciones de carácter bioético y el medio ambiente, es decir, se busca la protección de aquel conjunto de obligaciones de carácter bioético que tiene el hombre para con los animales, esta protección deriva de la relación existente entre la especie humana y la naturaleza.

c. Otra postura se refiere que el bien jurídico protegido son los intereses generales, entendida como aquella en la que se protegen los sentimientos del ser humano de no ver sufrir al animal, así como el mantenimiento de la paz de los ciudadanos, como función social que vendría a cumplir la norma de prohibición del maltrato animal; o por último como «seguridad ciudadana. 
d. También existe aquellos que señalan que el bien protegido es la integridad psíquica o física del animal como ser vivo. Es decir, por medio de este delito se protege la vida e integridad de los animales, es decir, supondría un reconocimiento de los derechos a la vida e integridad de los mismos, o, incluso, a su bienestar.

e. Los sentimientos de los seres humanos, es decir, lo que se pretende proteger son aquellos sentimientos de amor y compasión hacia los animales.

f. Otra postura señala que lo que se protege es la dignidad animal, así como su vida e integridad, su bienestar. (Jaurrieta, 2019)

Prats, Elena. (2020) señala que:

Existen diferentes posicionamientos al respecto:

Jaurrieta al hacer un seguimiento de las diferentes posiciones defendidas por la doctrina, distingue entre obligaciones de carácter moral, obligaciones de carácter bioético y el medio ambiente, intereses generales, integridad psíquica o física del animal como ser vivo, los sentimientos de los seres humanos y la dignidad del animal.

Brage Cendán, presenta diferentes teorías sugeridas que van desde señalar al medio ambiente, la moral pública y las buenas costumbres, los sentimientos de amor y compasión hacia los animales, los derechos subjetivos de los animales y el bienestar animal.

Ríos Corbacho, también hace un repaso de las diferentes posiciones sugeridas, indicando entre estas el medio ambiente, los intereses generales (que podría incluir aspectos tan diversos como la producción de valores culturales, la sensibilidad humana ante el sufrimiento de otros seres animales o el mantenimiento de la paz entre los ciudadanos), un bien jurídico colectivo, a la vida, integridad física y psíquica del animal e incluso su dignidad y, por último, a la satisfacción de intereses humanos.

De forma similar, Mesías Rodríguez, señala en relación a los posicionamientos mayormente defendidos por la doctrina sobre el bien jurídico protegido por el delito al interés general, las buenas costumbres, la integridad del animal, el medio ambiente, la dignidad del animal, el bienestar animal e, interesantemente, la inexistencia de bien jurídico.

Por su parte, Gavilán Rubio señala claramente tan sólo la vida y la salud del animal o, dicho de otro modo, la integridad física y psíquica del animal, mientras que:

Cervelló Donderis, en una línea similar, considera que el bien jurídico protegido sería el bienestar animal frente al maltrato y el sufrimiento, manifestado en la integridad física, psíquica y salud de los animales como seres vivos, atendida su capacidad de sentir emociones y de sufrir, y el derecho a no ser maltratados (p. $22-24$ )

Se advierte que no existe uniformidad de criterios respecto a cuál es el bien jurídico protegido de este delito, sin embargo, según una sentencia expedida el 06 de julio del año 2021, por el "Quinto Juzgado Penal Unipersonal Supraprovincial de Chiclayo-Ferreñafe por el delito de abandono y actos de crueldad contra animal doméstico, en el expediente signado con el número 06261-2020, establece textualmente lo siguiente: Considerando "2.1.2.- El bien jurídico que se preserva conforme al espíritu de la norma es a blindar la vida, y la integridad del semoviente considerado como ser sensible." 
Después de lo descrito, teniendo en cuenta la tendencia actual de la descosificación de los animales, que estos son merecedores de buen trato y que no se les debe maltratar ni causar actos de crueldad, se podría considerar que el bien protegido es el animal mismo, pues, el interés que se quiere salvaguardar es la vida, integridad y buen trato hacia los animales. Se entendería que se quiere salvaguardar la vida, integridad y buen trato de todos los animales vertebrados domésticos (vaca, pavo, cerdo, gallina, pollo) y silvestres mantenidos en cautiverio para que nadie les cause actos de crueldad ni los abandone.

Empero, respecto a la redacción de la segunda parte de dicho artículo, que textualmente establece que "...si como consecuencia de estos actos de crueldad o del abandono el animal doméstico o silvestre muere...", se es de la opinión que dicha redacción deba ser modificada, precisándose que es aplicable para los domésticos (salvo que sea para consumo humano) para los de compañía y los silvestres mantenidos en cautiverio.

Es decir, este extremo debe diferenciar y precisar a quién se aplica: i) a los domésticos, salvo que sea para fines de consumo humano (en cuyo supuesto no se aplicaría, más abajo se explica), salvo, que la finalidad de la norma haya sido que ningún peruano consuma ningún tipo de animal doméstico, ii) expresamente se precise a los de compañía y, iii) a los animales silvestres

Se procede a explicar lo expuesto:

i) La segunda parte del artículo citado textualmente prescribe que "si como consecuencia de estos actos de crueldad o del abandono el animal doméstico o silvestre muere, la pena es privativa de libertad no menor de tres ni mayor de cinco años, con ciento cincuenta a trescientos sesenta días multa y con inhabilitación de conformidad con el numeral 13 del artículo 36".

ii) Es de conocimiento por todos que, para lograr la venta y consumo de todo animal doméstico se le debe provocar y causar la muerte, esto es, que previo sometimiento del animal posteriormente se acaba con su vida. Este acto por sí mismo, constituye un acto de crueldad que se práctica sobre el animal doméstico (vaca, pavo, pollo, gallina, cerdo). Por ejemplo, al pollo le sacan las plumas, le tuercen el cuello o lo guillotinan y le provocan la muerte. A la vaca se la mata a cuchillazos, sofocados, degollados, azotados o triturados.

iii) Entonces, sí lo que efectivamente se busca con dicho delito es evitar todo acto de crueldad contra los animales domésticos y así evitar su muerte, no cabe duda que esto no se cumple cada vez que se los somete a muerte para el consumo humano. Efectivamente, se trata de un acto de crueldad que le provoca la muerte, cuya única finalidad es la de venderlos para el consumo humano.

iv) Por lo expuesto, salvo que la finalidad de la norma haya sido que ningún peruano consuma algún animal doméstico o se convierta en vegano; se considera que dicha norma jurídica debe estar mejor redactada. Es decir, solo es aplicable a aquellas muertes provenientes de actos de crueldad que se realizan contra los animales domésticos, salvo sea para consumo humano, para los de compañía (perro o gato $u$ otro animal a quien se le tenga un gran afecto y por ende no lo consumiría) y los silvestres. Ninguna persona que tiene un animal de compañía y que le trata como tal, terminaría matándolo y menos para su consumo y, sí en caso lo hiciera, ese acto constituye delito.

v) Asimismo, desde que entró en vigencia dicho delito, hasta la fecha solo se han presentados procesos por actos de crueldad o muerte contra los animales de compañía y ningún caso, por lo menos conocido, por un animal doméstico. 
vi) Por otro lado, el inciso c del artículo 27 de la Ley de Protección y Bienestar Animal - Ley 30407- solo prohíbe expresamente, que queda prohibida toda practica que pueda atentar contra la protección y bienestar de los animales de compañía, tales como: la crianza y el uso de animales de compañía con fines de consumo humano, no prohibiendo el consumo de otros animales. La ley citada no prohíbe el consumo de otro animal doméstico, por lo que sí uno le causa actos de crueldad a un animal de doméstico produciéndole la muerte para el consumo humano, esto no constituye ninguna infracción sancionada por la Ley de Protección y Bienestar Animal, pues, se siguen vendiendo y consumiendo animales domésticos.

vii) La redacción del segundo extremo del artículo quedaría así modificada: "si como consecuencia de estos actos de crueldad o del abandono el animal doméstico (salvo que sea para el consumo humano), el de compañía o el silvestre muere, la pena es privativa de libertad no menor de tres ni mayor de cinco años, con ciento cincuenta a trescientos sesenta días multa y con inhabilitación de conformidad con el numeral 13 del artículo 36".

¿Quién puede ser el sujeto activo de este delito?

El sujeto activo de este delito puede ser cualquier persona que realice actos de crueldad contra estos animales. Sujeto activo. Solo puede ser el hombre. (Serrano, 2004, p. 503). "entendemos que puede ser cualquier persona ya que no se exige ningún requisito o condición para efectuar la conducta típica [...] podrá ser sujeto activo el mismo propietario del animal, el poseedor, o un tercero, cualquiera que lleve a cabo este comportamiento con un animal, sea de su propiedad o no, sea su poseedor o no, podrá ser enjuiciado por este delito. Además, cabe apreciar, coautoría en estos delitos, que, aunque no son muy frecuentes (De Martín-Pinillos, 2018, p. 22)

La sentencia citada expedida por el "Quinto Juzgado Penal Unipersonal Supraprovincial de Chiclayo-Ferreñafe por el delito de abandono y actos de crueldad contra animal doméstico establece textualmente lo siguiente: Considerando "2.1.2.- ... El sujeto activo resulta ser cualquier persona, pues la descripción normativa no hace alusión a algún elemento especial para considerarse autor."

¿El sujeto pasivo de este delito quién sería?

Según Jiménez de Asúa (1965)

Para dejar definitivamente precisada la noción del sujeto pasivo, digamos que es preferible denominarle así y no víctima- aunque ambos vocablos se identifican- por la superior exactitud del primero, en tanto que la segunda de estas expresiones pertenece más bien al lenguaje común. También nos parece mejor designarle así que con el nombre de parte lesionada, puesto que el uso de esta frase- como observa Petrocelli (pág. 257) es predominante procesal. (...) Sujeto pasivo del delito es todo poseedor de un bien o de un interés jurídicamente protegido. Por consiguiente, lo son: el hombre, la persona jurídica, el Estado, o la colectividad. (..) nos hallamos, pues, en presencia de esos delitos llamados vagos, en que el sujeto pasivo es un grupo indeterminado de personas: familia, estirpe, colectividad". (...). (p.95-100)

Sujeto pasivo del delito es el titular del bien jurídico protegido. En este delito sería la colectividad, la sociedad, que se sentiría ofendida con el maltrato a los animales. (Serrano, 2004. P. 504). 
Respecto al sujeto pasivo existen diversas opiniones. "La determinación del sujeto pasivo viene condicionada por la concepción que se tenga sobre la teoría de la naturaleza del bien jurídico protegido en estos delitos" (De Martín-Pinillos, 2018, p. 22)

Los que entienden que los animales son sujetos de derechos entenderán que el sujeto pasivo del delito es el propio animal. Sin embargo, existe otra postura doctrinal, seguida por ejemplo por Gabriel García Planas, en la que se considera que el sujeto pasivo de estos delitos podría ser el dueño del animal o la colectividad, pero nunca el animal doméstico, ya que afirma que este no puede ser sujeto de derechos [...] Para los que no siguen la teoría del otorgamiento de derechos a los animales, sí que recae sobre ellos el objeto material del mismo, aunque no coincide con el sujeto pasivo. (De Martín-Pinillos, 2018, p. 24)

\section{Según Jiménez de Asúa (1965)}

Los sujetos pasivos de tales infracciones son los animales mismos, lo que, según hemos dicho, constituye un error en la doctrina penal imperante. Mejor orientada parecería [...] la exposición [...] que consideraba los delitos sancionados por esta ley como atentatorios a la cultura y moralidad públicas, contra el sentimiento social propio de un pueblo civilizado, cuya sanción trata de evitar que se despierten o fomenten en el hombre instintos o impulsos de crueldad hacia sus mismos semejantes" (p. 101)

Queda claro que tampoco existe uniformidad de criterios respecto a quién sería el sujeto pasivo. Si el sujeto pasivo de todo delito es el titular del bien jurídico protegido, sería, necesario que previamente se precise cuál es el bien jurídico protegido en este delito. Según lo descrito anteriormente (léase bien jurídico protegido), existen varias posturas respecto a cuál es el bien jurídico protegido, por lo que dependiendo de la posición que uno asuma, respecto al bien jurídico protegido, se podrá determinar quién es el sujeto pasivo de este delito.

Sin embargo, la sentencia antes citada, expresamente señala en el considerando "2.1.2.- ... El sujeto pasivo de la acción, conforme a la naturaleza del bien jurídico protegido, resulta ser el animal vertebrado (doméstico, o silvestre en cautiverio)"

Sin duda, corresponderá a la ley y a la doctrina respectiva, precisar cuál es el bien jurídico y cuál es el sujeto pasivo de estos delitos. Falta mucho por definir y precisar. De todos modos, no se puede dejar de reconocer el gran avance que ha significado para nuestro país la incorporación de este delito, pues, existen varias sentencias condenatorias para todo aquel que atente y realice actos de crueldad contra los animales de compañía.

\section{SENTENCIA EXPEDIDA POR EL QUINTO JUZGADO PENAL UNIPERSONAL SUPRAPROVINCIAL DE CHICLAYO - FERREÑAFE POR EL DELITO DE ABANDONO Y ACTOS DE CRUELDAD CONTRA ANIMAL DOMÉSTICO}

\section{RESOLUCIÓN NÚMERO: CUATRO Chiclayo, seis de Julio Del año dos mil veintiuno. -}

VISTA en audiencia oral y pública, llevada a cabo mediante el aplicativo Google Hangouts Meet, interviniendo como Juez del Quinto Juzgado Penal Unipersonal Supraprovincial de Chiclayo y Ferreñafe, la señora JANET CECILIA SÁNCHEZ CAJO, en calidad de Juez Supernumerario, luego del debate probatorio, procede a dictar sentencia, bajo los términos siguientes: 


\section{I.- PARTE EXPOSITIVA}

\section{1.- SUJETOS PROCESALES}

1.1.1.- PARTE ACUSADORA: DR. ENRIQUE SANCHEZ ESPEJO, Fiscal Adjunto Provincial de la Tercera fiscalía provincial Penal Corporativa de Chiclayo, con Casilla Electrónica N 108976.

1.1.2.- PARTE ACUSADA: YRIS SOBEIDA GONZALES RUBIO, identificado con Documento Nacional de Identidad $N^{\circ}$ 16702649, fecha de nacimiento 28/10/1971, natural de Chiclayo Lambayeque, nombre de sus padres Juan Carlos y Sobeida, grado de instrucción secundaria completa, estado civil soltera, ocupación - vendedora de libros, percibe S/ 400.00 Soles mensuales, no tiene apodos, no tiene tatuajes, no tiene cicatrices, no tiene bienes inscritos en registros públicos, domicilio real en la calle Independencia № 269, PP.JJ. San Antonio - Chiclayo. ABOGADO DEFENSOR: DR. ADEMAR ORTIZ SILVA, con registro ICAL $N^{\circ} 1192$, con casilla electrónica $\mathrm{N}^{\circ}$ 41701.

1.1.3. AGRAVIADO: JORGE OMAR DÍAZ URIARTE, identificado con Documento Nacional de Identidad $N^{\circ} 41640150$, con domicilio real en calle Jorge Arróspide $N^{\circ} 260$, Urb. Caja de Depósitos - Chiclayo - Lambayeque.

\section{2.- HECHOS MATERIA DE IMPUTACIÓN}

1.2.1.- DEL FISCAL CORTE SUPERIOR DE JUSTICIA DE LAMBAYEQUE QUINTO JUZGADO PENAL UNIPERSONAL SUPRAPROVINCIAL DE CHICLAYO Y FERREÑAFE EXP. N 06261-2020

a) Hechos materia de imputación: Manifestó que acreditará en juicio oral, la responsabilidad penal de la acusada YRIS SOBEIDA GONZALES RUBIO, en calidad de autora por el delito Contra El Patrimonio en su modalidad de Actos de crueldad contra animales domésticos, previsto en el artículo 206- $\mathrm{A}^{\circ}$ del Código Penal, en circunstancias que el agraviado Jorge Omar Díaz Uriarte el día veintisiete de diciembre de dos mil diecinueve, a las veinte con treinta horas sacó a orinar a su perrita "Cielo" a la calle San Luis del PP.JJ. San Antonio, miccionando en la tierra, al frente y lejos de la casa de la señora Yris Sobeida Gonzáles Rubio, pretendiendo ésta querer patear al can, procediendo el agraviado llevar a la perrita para su casa, soltándola para abrir la puerta, instantes en que la acusada arrojó una piedra de $5 \times 5 \mathrm{~cm}$ aproximadamente a la perrita "Cielo" impactándole debajo de su ojo derecho, gritando de dolor, hecho que fue observado por el señor Marcos Leyva Toro, testigo presencial de los hechos, dirigiéndose inmediatamente el agraviado a increparle su conducta a la acusada, negándose ésta en todo momento, entrando a su domicilio y no saliendo a pesar de que el agraviado le tocó la puerta en compañía de su esposa Tatiana Hernández Tineo y el señor Leyva Toro, conduciéndose éstos últimos a llevar al can de emergencia a la Clínica Mister Can, ubicada en la Av. Libertad $N^{\circ}$ 401- Urb. Santa Victoria, diagnosticándosele al can traumatismo ocular cerrado, causado por un cuerpo extraño, ocasionando hemorragia interna, inflamación alrededor del ojo, requiriendo tres días de atención con inyectables, analgésicos, antibióticas, además de gotas.

b) Sustento Jurídico: Los hechos antes descritos, fueron subsumidos por la representación fiscal en el delito Contra EI Patrimonio en su modalidad de ACTOS DE CRUELDAD CONTRAANIMALES DOMESTICOS, ilícito previsto y penado en el artículo 206- $\mathrm{A}^{\circ}$ del Código Penal, en agravio de JORGE OMAR DÍAZ URIARTE; por lo que solicitó se le imponga a la acusada YRIS SOBEIDA GONZALES RUBIO, UN AÑO DE PENA PRIVATIVA DE LIBERTAD, y CIEN DÍAS MULTA, como pena conjunta, equivalente a la suma de QUINIENTOS SOLES (S/500.00). INHABILITACIÓN por 
el mismo periodo de la condena, consistente en la INCAPACIDAD definitiva para la tenencia de animales domésticos conforme con al artículo $36^{\circ}$ numeral 13) del Código Penal; y una reparación civil ascendente a la suma de SEISCIENTOS SOLES (S/ 600.00).

c) Sustento Probatorio: Probará los hechos, con los medios probatorios admitidos en el auto de enjuiciamiento, consistentes, en: Testimoniales: Jorge Omar Díaz Uriarte, José Marco Leiva Toro, Tatiana Loreti Hernández De Diaz, Shirley Jenny Villalobos Paz; Documentales: Acta de denuncia verbal de fecha veintisiete de diciembre del dos mil diecinueve, Copia del acta de constatación policial de fecha veintisiete de diciembre del dos mil diecinueve, Panel Fotográfico, boletas de venta.

3 1.2.2.- DE LA DEFENSA Señaló que su patrocinada no es responsable del delito por el que se le imputa, tratándose de un caso de confusión y venganza, no habiéndose encontrado presente cuando sucedió el hecho de crueldad, habiéndose originado dicha denuncia porque la llamada de atención que su patrocinada realizó al agravio por hacer defecar a sus mascotas en la puerta de su casa en diferentes oportunidades.

1.3.- POSICIÓN DE LA ACUSADA FRENTE A LA ACUSACIÓN FISCAL. Luego que se le explicaran los derechos que le asistían en juicio y sobre todo la posibilidad que tenía de contradecir la prueba ofrecida por el fiscal; así como, que la presente causa pueda terminar mediante conclusión anticipada, la acusada YRIS SOBEIDA GONZALES RUBIO, previa consulta con su abogado defensor, manifestó que no se considera autora del delito materia de acusación ni responsable de la reparación civil. Disponiéndose se continúe el proceso con las formalidades de ley.

1.4.- NUEVO MEDIO DE PRUEBA El Ministerio Público y la defensa, no ofrecieron nuevo medio de prueba.

1.5.-EXAMEN DE LA ACUSADA YRIS SOBEIDA GONZALES RUBIO, identificada con Documento Nacional de Identidad $N^{\circ}$ 16702649. De forma libre y espontánea, dijo: El día veintisiete de diciembre del año dos mil diecinueve, a las ocho y media de la noche, llegó del trabajo junto con su hermana Nelly Gonzales Rubio, y encontró al señor Omar haciendo orinar a su perrita cerca a la puerta de su casa, procediendo a reclamarle, igual que en varias oportunidades le dijo de manera respetuosa que haga orinar y defecar a su perrita en otro lugar, porque iba a agarrar el excremento y lo iba tirar en su puerta de su casa, respondiendo éste que a él nadie podía decirle nada porque estaban en la calle, mentándole la madre, palabras soeces, señalándole ésta que era un malcriado y que lo iba a denunciar, cuando ya se encontraba abriendo la puerta de su casa, el chico regresó con intención de tirarle puñetes y patadas, no lo hizo porque le dijo que le iba a denunciar, tirándole puñetes y patadas por reiteradas veces a la puerta, las perritas ya se habían retirado, en ningún momento tuvo contacto con las perritas y no tienen la culpa, la culpa la tuvo el dueño que no les enseña donde deben hacer sus necesidades. Al interrogatorio del fiscal: Señaló que le indicó al chico en reiteradas veces que hiciera orinar y defecar a sus perritas en otra parte, los vecinos le dijeron que el chico hacía miccionar a su perrita tanto en la mañana como en la tarde, le indicó que no haga orinar a sus perritas porque su padre de noventa años barre todos los días; el chico no fue a su casa con intención de golpearla, ya estaba ahí en el lugar, luego de terminada la discusión el señor se fue y solo atinó a meterse a su casa junto con su hermana, luego de eso ya no volvió a tener contacto con el señor. El representante del Ministerio Público al advertir una contradicción, solicitó la incorporación de la declaración escrita de fecha veinticinco de Febrero del dos mil veinte, respecto a las pregunta número cuatro, procediendo a dar lectura en los términos siguientes: ¿Para que diga: Que tiene que decir ante la sindicación realizada por la persona de Jorge Omar Díaz Uriarte, respecto a que el día veintisiete de diciembre del dos mil diecinueve, 
usted habría arrojado una piedra a su mascota Cielo, que le cayó debajo de su ojo derecho?...yo le dije que lo voy a denunciar, entonces él se fue, luego él ha regresado con una perrita en sus brazos diciendo que yo le he tirado una piedra, lo cual es falso. Continuando con el interrogatorio, dijo sí denunció al señor en la comisaria de Campodónico, el mismo día veintisiete de diciembre del dos mil diecinueve, pasando las nueve de la noche, como no sabía el nombre del señor fue con efectivos policiales a la casa del señor, salió el señor y su esposa, dijo que su mamá era fiscal en Tumbes, que tenía influencias, que no sabía con quien se metían y que esto no se iba a quedar así; ella narró al policía todo lo sucedido, pero el policía volvió a constatar si hubieron daños materiales pero como la puerta es de madera no había ningún daño. Al interrogatorio de la defensa: No realizó preguntas. Aclaraciones de la señora Juez: Señaló cuando el señor comenzó a golpear la puerta, las perritas ya se habían retirado, la discusión fue con el señor, más aún cuando sus manos estaban ocupadas con los libros que traía consigo.

\section{6.-ACTIVIDAD PROBATORIA}

\subsection{1.-DEL MINISTERIO PÚBLICO}

1.6.1.1.- PRUEBA TESTIMONIAL a). - De Jorge Omar Díaz Uriarte, identificado con Documento Nacional de Identidad $N^{\circ} 41640150$, con domicilio real en calle Jorge Arróspide $N^{\circ} 260$, Urb. Caja de Depósitos - Chiclayo - Lambayeque. Al interrogatorio Fiscal: Señaló si tiene conocimiento el motivo de su citación al juicio; no conoce a la acusada Yris Sobeida Gonzales Rubio, vive en la casa de su esposa desde hace dos años que se casaron, no tiene ningún grado de amistad ni enemistad con la acusada; la casa de su esposa está ubicada en la calle Independencia $N^{\circ} 231$, se encuentra a tres puertas de distancia de la casa de la acusada; todas las noches que llega del trabajo sale a pasear a sus perritos, las sacó a pasear al frente de la casa de la señora Yris, pasó por un poste y se percató que una de sus perritas gritó como si le hubieran hecho algo, se dio cuenta que la hermana de la acusada pateó a su perrita y le dijo por qué no hace orinar a sus perritas en su casa, a lo que respondió que era un poste donde no hay ninguna casa, su casa estaba al frente y su perrita como es pekinés orinó solo dos gotitas, le dijo no tenía por qué patear a los animales y si tenía tanto odio a los animales no tenía que patearlos, se fue con sus perritos a su casa, bajó a sus perritos al suelo, abrió la puerta de la casa, y su perrita gritó de dolor, no se percató en el momento donde le cayó la piedra que tiraron, estaba oscuro, entró a su casa y ve el ojo de la perrita inflamado con sangre y hemorragia, su esposa gritó, lloró, se desesperó, él también se desesperó, le contó a su esposa que la señora Yris le tiró la piedra, fueron a increparla pero fue tan cobarde que no les dio la cara, se encerró en su casa, le tocó la puerta y nadie salió, el único testigo fue el señor Marcos, quien le preguntó qué pasaba y le contó que le tiraron una piedra a su perrita, el señor contestó que a él también casi le cae una piedra por su pierna, y le dijo que la señora era mala por meterse con los animales, luego agarraron a su perrita y en su carro la llevaron a la clínica, donde señalaron que tenía el ojo inflamado a raíz de una piedra que le tiró la vecina, la doctora le puso antibióticos toda la semana y a raíz de ese tiempo puso la denuncia por la piedra que le tiraron a su perrita; en el lugar no había nada, solo el vecino Marcos que estaba sentado en la puerta; no discutió con nadie porque la señora se encerró; antes que le tiren la piedra discutió con una de las hermanas de la acusada que pateó a su perra y la otra hermana le tiró la piedra a su perrita; la piedra la tiró la señora Yris; el señor Marco le dijo que la señora era mala persona por tirar la piedra que pudo caerle a cualquier persona. Al contrainterrogatorio de la defensa: Ninguna pregunta.

b).- De José Marco Leyva Toro, identificado con Documento Nacional de Identidad № 16423087 , con domicilio real en calle Independencia $N^{\circ} 225$, PP.JJ. San Antonio - Chiclayo. Conoce a la acusada porque es su vecina del barrio. Al interrogatorio Fiscal: Señaló su domicilio se encuentra a cinco o 
seis puerta de la casa de la señora Yris Sobeida Gonzales Rubio, en diciembre del año dos mil diecinueve a las ocho y media de la noche, estaba sentado afuera de la iglesia de Nazaret, había llegado del trabajo y estaba descansando, en ese momento llegó su vecino Omar y su vecina Tati en su carro, bajaron sus perritos y uno de ellos se escapó para el lado de la casa de la vecina Yris, el perrito se orinó en medio de la pista, en ese momento vino la señora Yris y la señora Sara, de lejos veía que la señora Yris estaba reclamando al señor Omar por motivo que se había ocupado el perrito, el vecino regresaba con sus perritos a su casa, justo llegando a su casa le tiraron una piedra al perrito que le cayó en su ojo, a él le cayó en la pierna, su vecina estaba parada en la puerta, vieron que el perrito le cayó la piedra y se privó de dolor, al ver esas cosas su vecina se soltó de nervios y su vecino Omar se fue a tocarle la puerta a reclamarle a la señor Yris porqué le pegó al perrito, su vecino al ver que no salía nadie se regresó y llevó a la clínica al perrito, hasta ahí fue donde vio; la calle es sólida, solamente alcanzó a ver a sus dos vecinos, pero si vio cuando su vecina Yris tiró la piedra al perrito; estaba sentado al costado de la casa de la vecina Tati, afuera de la iglesia Nazaret, en la parte izquierda donde siempre se sienta; el señor Omar no logró ver cuando la señora Yris tiró la piedra ya que estaba de espaldas, fue su persona quien vio ese hecho y le avisó; la vecina Tati no vio quien tiró la piedra ya que estaba parada en su puerta. Al contrainterrogatorio de la defensa: Indicó el señor Omar llegó con su esposa en su carro, bajaron a sus mascotas y uno de sus perritos se le escapó a orinarse, justo venía la señora Yris con su hermana, la señora Sara comenzó a reclamarle al vecino Omar, el vecino ya estaba regresándose a su casa y la vecina tiró la piedra al perrito que pasó por su pierna, al ver que le cayó la piedra en el ojito de la perrita, el vecino Omar fue a reclamarle a la señora Yris. La defensa al advertir una contradicción, solicitó la incorporación de la declaración escrita rendida en sede fiscal, respecto a las pregunta número cuatro, procediendo a dar lectura en los términos siguientes ¿Para que diga, si usted se percató qué persona le lanzo la piedra que le cayó a la mascota Omar Díaz Uriarte?, dijo "no sabía quién era, ahora según lo que me conversó mi vecino Jorge, es que ha sido la vecina de la esquina, la señora Yris Gonzales, pero yo no vi, solamente vi que pasó la piedra cerca de donde estaba sentado. Redirecto del fiscal: Señaló primero indicó que no vio a la persona que tiró la piedra a la perrita porque nunca tuvo problemas con nadie, ambas partes son sus vecinos y quiso apaciguar las cosas, pero recapacitó y en audiencia declaró sobre lo que en verdad pasó. Aclaraciones de la señora Juez: Señaló la calle estaba solitaria, solo estaba ese día el vecino Omar, la vecina Tatiana, la vecina Sara y la vecina Yris.

c). - De Tatiana Loreti Hernández De Díaz, identificado con Documento Nacional de Identidad $\mathrm{N}^{\circ}$ 46032059, con domicilio real en calle Independencia $\mathrm{N}^{\circ} 231$, PP.JJ. San Antonio - Chiclayo. Al interrogatorio Fiscal: Señaló sí conoce a la señora Yris Sobeida Gonzales Rubio, es su vecina desde hace muchos años, sólo había saludos cordiales de vecinos; sí tiene conocimiento de los hechos por los que fue citada a juicio; recuerda que en diciembre del año dos mil diecinueve, llegó del trabajo, eran los ocho y media aproximadamente y al momento de entrar a su domicilio, su perrita Cielo sale y su esposo va detrás de las dos perritas, se quedó en la puerta de la casa, no se percató en qué momento su perrita llegó corriendo y vio que le cayó una piedra en su vista y se retorció de dolor, la perrita entró a la casa y en eso llegó su esposo, alzó a la perrita y vio que su perrita esta ensangrentada, se soltó de los nervios al verla y recuerda haber visto a su vecino Marcos sentado en un muro de la iglesia y éste le dijo que fue la señora Yris quien tiró la piedra, en ese momento junto con su esposo fueron a su casa de la señora, tocaron la puerta duro y llorando porque estaba desesperada y nadie les abría, al otro lado vive el señor José Gonzales, quien es hermano de la señora Yris y él si salió, pudiéndole mostrar a su perrito y le dijo "mire lo que le ha hecho su hermana Yris a mi perrita, por qué es tan cruel", a lo único que el señor le respondió "qué barbaridad", luego junto a su esposo y la perrita fueron a la veterinaria Mistercan, ahí la doctora atendió a su perrita y le diagnóstico traumatismo ocular por objeto contundente, tuvo tratamiento a base de inyecciones, analgésicos y gotas, no perdió la vista y pudo recuperarse, la única persona que estaba presente 
en los hechos y que vio todo lo que sucedió fue el señor Marcos Leyva. Al contrainterrogatorio de la defensa: Ninguna pregunta.

d). - De Shirley Jenny Villalobos Paz, identificado con Documento Nacional de Identidad $\mathrm{N}^{\circ}$ 16615345, con domicilio real en calle Fraternidad N ${ }^{\circ} 649$, La Victoria - Chiclayo. Al interrogatorio Fiscal: Señaló es médico veterinario por más de veinte años, labora actualmente en la veterinaria Mistercan; si recuerda sobre la perrita que atendió, los propietarios de la perrita la llevaron a la veterinario tipo emergencia debido a que la vista del animalito estaba inflamada y tenía lagrimas sanguinolentas o mejor dicho el líquido que sale del ojo esta enrojecido; preguntó a los dueños que había pasado pero ella determinó que fue un trauma por golpe; a la perrita se le dio los primeros auxilios, se limpió su ojo y también como había una lesión interna se le recetó unas gotas cicatrizantes ya que la lesión podría haber ocasionado ulceras; si la perrita no hubiera sido atendida hubiera podido tener ulceras oftálmicas. Al contrainterrogatorio de la defensa: Ninguna pregunta. Aclaraciones de la señora Juez: Señaló, el traumatismo le ocasionó un golpe por objeto, no puede especificar que objeto pudo haber sido, pudo ser golpe, un palo, una piedra, incluso un carro que pudo haber atropellado a la perrita.

\subsubsection{2.- PRUEBA DOCUMENTAL}

1. ACTA DE DENUNCIA VERBAL DE FECHA VEINTISIETE DE DICIEMBRE DEL DOS MIL DIECINUEVE. APORTE DEL FISCAL: El agraviado expresó de manera espontánea, el mismo día de los hechos, como es que sucedieron los hechos materia de investigación. OBSERVACIÓN DE LA DEFENSA: Observa que no se indica de que perrito se trata ni de que ojo de la perrita fuera lesionado.

\section{COPIA DEL ACTA DE CONSTATACIÓN POLICIAL DE FECHA VEINTISIETE DE DICIEMBRE} DEL DOS MIL DIECINUEVE. APORTE DEL FISCAL: Acredita que la acusada denunció al señor Diaz Uriarte por daños a su domicilio. OBSERVACIÓN DE LA DEFENSA: Su patrocinada fue a la comisaria a denunciar el hecho.

3. Panel Fotográfico. APORTE DEL FISCAL: El ojo de la mascota fue sujeto de una lesión. OBSERVACIÓN DE LA DEFENSA: No se indica de qué perrito se trata ni de que ojo de la perrita fue lesionado.

4. Boletas de venta. APORTE DEL FISCAL: Acredita que se realizó tratamiento en la clínica Mistercan, por daño ocular y se gastó la suma de doscientos soles (S/ 200.00) OBSERVACIÓN DE LA DEFENSA: Las documentales no vinculan a su patrocinado con el delito

1.6.1.-DE LA DEFENSA 1.6.1.1.- PRUEBAS TESTIMONIALES 8 a). - De Shirley Luz Karina Castañeda Palomino, identificado con Documento Nacional de Identidad $N^{\circ} 46185310$, con domicilio real en calle Independencia $N^{\circ} 300$, PP.JJ. San Antonio - Chiclayo. Al interrogatorio de la defensa: Señaló sí tiene conocimiento del porqué fue citada a la audiencia; conoce a la señora Yris Gonzales Rubio ya que son vecinas, está en audiencia, es injusto de lo que la están acusando, todas las noches abre su puerta porque sale a jugar su hijo, un cuarto para ser las nueve, la señora Sara y la señora Yris llegaban del trabajo, siempre ve a su vecino Omar que en la mañana y noche sacan a su perrito y hacen ahí sus necesidades en toda la calle San Luis, ese día vio que la señora Yris le comenzó a reclamar al señor Omar porqué sus perritos estaban defecando, a su parecer el señor estaba mareado porque estaba insultando, hasta pareció que le quería tirar un puñete, lo pensó bien y dio puñetes y patadas a la puerta de la casa, las vecinas se asustaron y se entraron a su 
casa, luego ya al rato vio salir a la señora Yris, ya no vio nada más. Contrainterrogatorio Fiscal: Manifestó es vecina de la señora Yris; cuando doña Yris le pide al señor Omar que retire con sus perritos, fue el señor Omar quien comenzó a hacer problema y gritar, parecía borracho porque ninguna persona normal actúa de esa manera; nadie estaba presente en el lugar, las perritas ya no estaban en el lugar cuando el señor Omar tiró puñetes a la puerta. Aclaraciones de la señora Juez: Manifestó estaba visualizando los hechos desde la puerta de su casa, que queda en la esquina de la casa de la señora Yris; no pudo observar que pasó con las perritas porque cuando pasó la discusión las perritas no estaban presentes.

b). - De Sara Nelly Gonzales Rubio, identificado con documento Nacional de Identidad N 16474807 , con domicilio real en calle Independencia N²69, PP.JJ. San Antonio - Chiclayo. Al interrogatorio de la Defensa: Indicó es hermana mayor de la acusada Yris Gonzales Rubio, se encuentra en audiencia como testigo de un caso de maltrato animal; el día veintisiete de diciembre del dos mil diecinueve, iba llegando del trabajo con su hermana a las ocho y media de la noche, cada una con su maletín y libros de derecho, al llegar a su casa que queda en toda la esquina de la calle Independencia y San Luis, dos calles pequeñas, la calle San Luis no está pavimentada, es tierra, sus padres se encargan de barrerla todos los días, llegaron del trabajo con su hermana y encontraron al señor Omar con sus dos perritas, estaban haciendo sus necesidades, en reiteradas veces su hermana le dijo al señor Omar que no haga eso, sus padres comen casi en la puerta de la casa y no es justo que cuando abran la ventana y la puerta entren esos olores; esa noche su hermana se acercó al señor Omar y le dice "señor, nuevamente usted haciendo orinar a sus perros, acaso no entiende", las perritas terminaron de hacer el popo y corrieron hacia su casa, el señor le responde a su hermana "a mí nadie me dice nada vieja de m", incluso se asustó con esas palabras, pero su hermana volvió a decirle al señor "te gustaría que agarre ese excremento y lo tire en tu puerta, asqueroso" y vino a querer pegarle a mi hermana, mi hermana le dijo "pégame pues, para que veas como te denunció", como no le pegó, comenzó a golpear y patear la puerta, ella no decía nada porque estaba atónita por lo agresivo que estaba el señor, luego el señor se cansó de golpear la puerta y se fue a su casa, luego entraron a su casa y después de un rato su hermana le dijo que 9 iba a denunciar al señor porque si no iba a seguir así, pasó media hora salió su hermana y se fue a la comisaria, pero ella se quedó en su casa, ya no la acompañó. Al contrainterrogatorio Fiscal: Indicó el señor Omar dio puñetes y patadas a la puerta. El representante del Ministerio Público al advertir una contradicción, solicitó la incorporación de la declaración escrita de fecha uno de octubre del dos mil veinte, respecto a la pregunta número cuatro, procediendo a dar lectura en los términos siguientes: ¿Para que diga: En vista de qué usted indica que ha sido testigo presencial de los hechos materia de investigación, ¿narre la firma y circunstancias en qué tales hechos ocurrieron? Dijo (...) luego que el señor Omar después de dejar a sus perras y regresa a nosotros y nos encuentra en la puerta todavía tocando para entrar, luego viene con más violencia, quería darle un puñete a mi hermana, qué pensaría no lo hizo y empezó a golpear mi puerta con puñetes y patadas. Aclaraciones de la señora Juez: Indicó el señor Omar se encontraba a seis pasos de distancia de la puerta de su casa; las perritas al terminar de hacer sus necesidades voltearon y se fueron hacia su casa, ya no volvieron a ver a las perritas.

\section{II.- PARTE CONSIDERATIVA}

\section{1.- DESCRIPCIÓN DE LAS NORMAS APLICABLES AL CASO.}

2.1.1.- El Representante del Ministerio Público, ha calificado los hechos dentro del artículo doscientos seis - A del Código Penal, es decir, el delito Contra el Patrimonio en su modalidad de Actos de crueldad contra animales domésticos, previsto en el artículo 206- $A^{\circ}$ del Código Penal, debiendo analizarse los elementos objetivos y subjetivos del tipo. 
2.1.2.- El bien jurídico que se preserva conforme al espíritu de la norma es a blindar la vida, y la integridad del semoviente considerado como ser sensible. El sujeto activo resulta ser cualquier persona, pues la descripción normativa no hace alusión a algún elemento especial para considerarse autor. El sujeto pasivo de la acción, conforme a la naturaleza del bien jurídico protegido, resulta ser el animal vertebrado (doméstico, o silvestre en cautiverio).

2.1.3.- Sobre los actos de crueldad, la norma lo define como: todo acto que produzca dolor, sufrimiento, lesiones o muerte innecesaria de un animal. V. gr., el inhumano joven que corta una de las extremidades de su perro; o cuando el gato, para conseguir su muerte, es arrojado por su dueño a una jauría de pitbulls terrier, castrar con una navaja a un perro callejero.

2.1.4.- Es un delito doloso. El autor encamina su conducta a "abandonar" o "cometer actos de crueldad" en perjuicio del animal. El aspecto cognitivo del dolo es fundamental en el injusto, pues la culpa no se admite dentro de la esfera de la tipicidad subjetiva.

\section{2.- VALORACION DE LAS PRUEBAS POR LAS PARTES.}

2.2.1.- Del Ministerio Público Señaló a lo largo del juzgamiento logró acreditar más allá de toda duda razonable, la responsabilidad penal de la acusada Yris Sobeida Gonzales 10 Rubio, como autora del delito de actos de crueldad contra los animales domésticos. Se logró acreditar con la declaración del testigo Marcos Leyva Toro, que fue la acusada quien cogió una piedra y la arrojó contra la perrita de nombre Cielo, de propiedad del agraviado Omar Diaz Uriarte, el día veintisiete de diciembre del dos mil diecinueve, encontrándose dicho testigo en la puerta de la iglesia evangélica que queda cerca al lugar de los hechos y presenciando el preciso momento del acto de crueldad materia del presente proceso, indicando que la piedra que le cayó a la perrita pasó cerca de sus pies y a pesar que la defensa técnica ingresó una contradicción en su declaración, la misma fue justificado válidamente por el testigo Leyva Toro, quien señaló que ha recapacitado y que si bien inicialmente dijo que no sabía quién había arrojado la piedra por el motivo de que son vecinos y al ver que el problema no se solucionó es que en el plenario señaló como realmente sucedieron los hechos, esto es, que fue la acusada Yris Sobeida Gonzales Rubio quien le arrojó la piedra a la perrita del agraviado. Con la misma declaración del señor Leyva Toro, se logró acreditar que la señora Yris reclamó al agraviado porqué su perro se encontraba orinando cerca de la casa de ella. Con la declaración del agraviado Omar Díaz Uriarte y de su esposa Tatiana Hernández Tineo, se logró acreditar que el día de los hechos al llegar de su trabajo, su mascota Cielo salió y orinó cerca de la casa de la señora Yris Gonzales Rubio, producto de ello la acusada le reclamó y que fue el señor Marco Leyva Toro, quien les dijo que fue la acusada quien arrojó la piedra a su perrita, la cual cayó en su ojo derecho, además que la acusada antes de tirar la piedra, intentó patear a la perrita por la parte de atrás, hecho que también está consignado en la denuncia verbal oralizada en el juzgamiento, con lo que se acredita que la acusada tuvo contacto con la perrita del agraviado, siendo que ello aunado al reclamo airado por parte de la acusada, así como la lesión causada a la perra, les permitió determinar más allá de toda duda razonable, que la persona que tiró la piedra fue la acusada como consecuencia de su enojo. Respecto a la declaración se la señora Sara Nelly Gonzales Rubio, hermana de la acusada, su declaración debe ser valorada de acuerdo a las reservas que atañen al proceso, puesto que es hermana de la acusada y dicho vinculo filial a todas luces generó una declaración exculpatoria a favor de su hermana, asimismo, se debe tomar en cuenta la contradicción que se realizó en su declaración en sede fiscal y que fue ingresada en el plenario, contradicción que no fue justificada por ella, en el sentido que, señaló que el presunto intento de agresión de parte del agraviado hacia la acusada fue en el mismo instante en que ella y su hermana llegaron a su domicilio después del trabajo, encontrando al agraviado con sus perras que estaban orinando afuera 
del domicilio de ella, siendo que en su declaración previa señaló que tal hecho ocurrió cuando el agraviado regresó hacia ellas, luego de dejar a los perritas en su casa, incluso quedó registrado en audio y video que ella misma dijo que su declaración es falsa, por lo que, no se le puede dar valor probatorio exculpatorio a esa declaración. Con la declaración de la acusada Yris Sobeida Gonzales Rubio, se acreditó su presencia en el lugar de los hechos, en la hora y fecha del hecho materia de acusación, habiendo señalado que vio a las perras orinando y que discutió con el agraviado por ello y con el afán exculpatorio negó haber arrojado la piedra a la perrita, sin embargo, su versión debe ser valorada teniendo en cuenta la contradicción con su declaración previa que fue ingresada en el plenario y que no fue justificada por la acusada, puesto que en sede fiscal señaló que el agraviado regresó con una perrita entre sus brazos y que le reclamó por haberle tirado la piedra y en el plenario señaló que el agraviado ya no regresó a su casa después de la discusión que tuvieron. Con la declaración de Luz Karina Castañeda Palomino, la cual no resultó conducente a acreditar la teoría del caso de la defensa técnica, debido a que señaló que al momento de la discusión entre la acusada y el agraviado ya no se encontraban las perritas, lo cual no se ajusta a la verdad ya que con la prueba actuada en juicio se demostró que la acusada si tuvo contacto con la perra cielo, además debido a que señaló que vio el hecho desde su casa, ya que vive en la cuadra tres y la acusada vive en la cuadra dos, siendo que la distancia que existe entre las dos casas no permitió que aprecie de manera clara el hecho materia de acusación, máxime si no pudo observar que pasó con las perritas. Con la declaración de la médico veterinaria Jenny Villalobos Paz, se logró acreditar que la perra Cielo ingresó el día veintisiete de noviembre del dos mil diecinueve por emergencia a la clínica Mistercan, ya que tenía la vista inflamada con lagrima sanguinolentas, esto debido a las lesiones internas en el ojo de la perra, por lo que se administró gotas cicatrizantes, desprendiéndose que la lesión que se causó a la perra fue de gravedad, de no haber recibido atención veterinario, habría conllevado a que la perrita contraiga ulceras oftálmicas y consecuentemente el retiro del ojo de la perra, lesión que fue visualizada en el panel de fotos actuado en el plenario. La declaración dada por la acusada, su hermana Sara y la señora Luz Castañeda Palomino, respecto a que el agraviado quiso agredir con puñetes a la acusada se vio desvirtuada con el contenido del acta de constatación policial de fecha veintisiete de diciembre del dos mil diecinueve, que fue oralizada en audiencia en donde de manera espontánea, la acusada en ningún extremo refirió dicha agresión, limitándose a indicar que el agraviado fue a golpear su puerta con golpes y patadas porque refirió que la acusada había maltratado a su perra, siendo que resulta ser un medio de defensa creado a fin de desacreditar la versión de la parte agraviada, es por ello que el Ministerio Público considera que no se logró acreditar la tesis de la defensa técnica indicado en sus alegatos de apertura, respecto a que señaló que la acusación fue por una confusión o venganza, no habiéndose acreditado medio de prueba alguno que acredite lo mencionada. Por lo expuesto, el representante del ministerio público se ratificó y solicitó se le imponga a la acusada YRIS SOBEIDA GONZALES RUBIO, UN AÑO DE PENA PRIVATIVA DE LIBERTAD. CIEN DÍAS MULTA que equivalen a la suma de QUINIENTOS SOLES (S/500.00), e INHABILITACIÓN por el mismo periodo de la 12 condena, consistente en la INCAPACIDAD definitiva para la tenencia de animales, conforme con al artículo $36^{\circ}$ numeral 13) del Código Penal. Asimismo, como reparación civil solicitó la suma de SEISCIENTOS SOLES (S/ 600.00).

2.2.2.- DE LA DEFENSA Señaló después de escuchar al fiscal que indicó un maltrato animal en el cual existen muchas dudas, ya que no pudo desvirtuar que la señora Yris Sobeida Gonzales Rubio, haya ocasionado hecho alguna de tal naturaleza, de los hechos quedó acreditado que el señor Omar siempre llevó a orinar a sus perritas, siendo que el día veintisiete de noviembre del dos mil diecinueve a las ocho y cuarenta y cinco de la noche, se le llamó la atención de manera reiterada y se enojó por este hecho, él mismo mandó a las perritas a su casa y empezó a insultar a su patrocinada, mentarle la madre, siendo tanta su ira porque su patrocinada le dijo que lo iba a denunciar, por lo que empezó a patear la puerta y tanto su patrocinada como su hermana se refugiaron dentro de 
su casa porque veían la ira de este señor, estos hechos fueron corroborados con las testimoniales de Luz Karina Castañeda Palomina y Sara Nelly Gonzales Rubio; posteriormente su patrocinada fue a la comisaria a denunciar el hecho y de eso existe una denuncia policial que la fiscalía obvio como medio probatorio, siendo el supuesto único testigo de los hechos, el señor Marco Leyva Toro, quien señaló que estaba sentado a treinta metros, siendo una mentira porque en su declaración en sede fiscal dijo que no vio quien tiro la piedra, por lo que no se puede confiar en una persona que mintió ante el órgano jurisdiccional. La veterinaria señaló que la lesión de la perrita pudo haberse causada por un palo u objeto contundente, pero no mencionó en ningún momento que haya sido por una piedra, además de ello no mencionó el nombre de la perra que atendió, ni que ojo estaba lastimado por lo que debe ser valorado por el órgano jurisdiccional. Con respecto a los gastos que dice haber realizado el agraviado no fueron materia de contradictorio ya que no aparecían ni los números, nombres o de que se trataba, incluso pudo tratarse de otro animalito porque no se señala ni el día ni la hora en que fue atendido el perrito, por estas razones creen que el motivo de la denuncia fue por motivo de odio, confusión o venganza, ya que al decirle su patrocinada que iba a denunciar al agraviado, es que este tomó la decisión de sacar un certificado médico y de denunciar conforme se señala en el atestado policial que cuando la policía llegó, el agraviado ya había denunciado la supuesta agresión animal, siendo un hecho muy raro que a las nueve de la noche haya podido denunciar el hecho, por lo que su teoría de que su patrocinado no se encontraba presente en el lugar de los hechos ni tiró ninguna piedra al animalito, es más contundente, con evidencias, testimoniales que corroboran su teoría, al contrario de la tesis fiscal que es dudosa, teniendo un único testigo, por lo que se debe tener en cuenta que su patrocinado no realizó ningún maltrato, habiendo insuficiencia de pruebas, por lo que de conformidad con el artículo $2^{\circ}$ párrafo 24 , inciso d) de la Constitución Política del Perú, así como el artículo $8^{\circ}$ de la Convención Americana de Derechos Humanos, se considere que no existen pruebas 13 suficientes para enervar la presunción de inocencia por insuficiencia probatoria, solicita la absolución de su patrocinada.

2.2.- AUTODEFENSA DE LA ACUSADA Señaló que está conforme con lo señalado por su abogado defensor, agregó que la discusión que tuvo fue con el señor Omar, no con las perritas, además si la discusión se realizó en la calle San Luis como es que pudo caerle la piedra al señor Marco Leyva si este se encontraba sentado en la calle Independencia, siendo algo ilógico, pide justicia porque la afectada es su persona por la mala conducta del supuesto agraviado, siendo machista de su parte por haberla agredido mentándole la madre, solo está excusándose con esta denuncia de maltrato animal que ella no realizó.

\section{TERCERO: DE LA VALORACION JUDICIAL DE LAS PRUEBAS}

3.1.- HECHOS PROBADOS: Respecto de los hechos objeto de imputación, del debate probatorio se ha llegado acreditar lo siguiente:

3.1.1.- Se ha acreditado, que el día veintisiete de diciembre del dos mil diecinueve, la persona de Jorge Omar Díaz Uriarte, a las veinte con treinta horas, conjuntamente con su perrita Cielo, estuvieron en la calle San Luis del PP.JJ. San Antonio, lugar donde el can miccionó. Conforme a la Declaración de la acusada Yris Sobeida Gonzáles Rubio, declaración de Jorge Omar Díaz Uriarte, declaración de José Marco Leyva Toro, declaración de Tatiana Loreti Hernández De Díaz, declaración de Shirley Luz Karina Castañeda Palomino, declaración de Sara Nelly Gonzales Rubio, Acta de denuncia verbal de fecha veintisiete de diciembre del dos mil diecinueve.

3.1.2.- Se ha acreditado, que en circunstancias en que la persona de Jorge Omar Díaz Uriarte, llevaba a su perrita Cielo a su casa, la soltó para abrir la puerta, instantes en que la señora Yris 
Sobeida Gonzáles Rubio, arrojó una piedra de $5 \times 5 \mathrm{~cm}$ aproximadamente a la perrita, impactándole debajo de su ojo derecho, gritando de dolor. Conforme a la Declaración de Jorge Omar Díaz Uriarte, declaración de Tatiana Loreti Hernández De Díaz, declaración de José Marco Leyva Toro, Acta de denuncia verbal de fecha veintisiete de diciembre del dos mil diecinueve, Panel Fotográfico.

3.1.3.- Se ha acreditado, que luego de haber sido agredida la perrita Cielo, la persona de Jorge Omar Díaz Uriarte, se dirigió inmediatamente a increparle su conducta a la señora Yris Sobeida Gonzáles Rubio, quien negó los hechos todo instante, ingresando a su domicilio y no salir, pese que el agraviado le tocó la puerta. Conforme a la declaración de Jorge Omar Díaz Uriarte, declaración de Tatiana Loreti Hernández De Díaz, declaración de José Marco Leyva Toro, declaración de Sara Nelly Gonzales Rubio rendida en sede fiscal ingresada por contradicción, Acta de denuncia verbal de fecha veintisiete de diciembre del dos mil diecinueve, Copia del acta de constatación policial de fecha veintisiete de diciembre del dos mil diecinueve. 3.1.4.- Se ha acreditado, que las personas de Jorge Omar Díaz Uriarte en compañía de su esposa Tatiana Hernández Tineo, condujeron a la perrita Cielo de emergencia a la Clínica Mister Can, ubicada en la Av. Libertad $N^{\circ}$ 401- Urb. Santa Victoria, diagnosticándosele traumatismo ocular cerrado, causado por un cuerpo extraño, ocasionando hemorragia interna, inflamación alrededor del ojo, requiriendo tres días de atención con inyectables, analgésicos, antibióticas, además de gotas. Conforme a la declaración de Jorge Omar Díaz Uriarte, declaración de Tatiana Loreti Hernández De Díaz, declaración de José Marco Leyva Toro, declaración de Shirley Jenny Villalobos Paz, Acta de denuncia verbal de fecha veintisiete de diciembre del dos mil diecinueve, Panel Fotográfico, cuatro boletas de venta.

3.1.5.- Se acreditado, que las lesiones producidas a la perrita Cielo, como respuesta al golpe proferido con la piedra, han sido producidas con voluntad de causar daño en la integridad corporal del can. Conforme a la declaración de Shirley Jenny Villalobos Paz y documento expedido por la clínica veterinaria Mister Can con fecha veintisiete de diciembre del dos mil diecinueve.

\subsection{HECHOS NO PROBADOS:}

3.2.1.- No se ha acreditado, que la persona de Jorge Omar Díaz Uriarte, el día veintisiete de diciembre del dos mil diecinueve, haya tenido algún otro altercado por el accionar de su perrita Cielo, con persona diferente a la acusada Yris Sobeida Gonzáles Rubio.

3.2.2.- No se ha acreditado, la teoría del caso de la defensa, en el extremo que su patrocinada no es responsable de la imputación efectuada, tratándose de una confusión y venganza.

3.2.3.- No se ha acreditado, la teoría del caso de la defensa, en el extremo que su patrocinada el día veintisiete de diciembre del dos mil diecinueve, no se encontraba presente cuando sucedió el hecho de crueldad respecto de la perrita Cielo.

3.2.4.- No se ha acreditado, la teoría de la defensa en cuanto que la denuncia efectuada por el agraviado obedezca a la llamada de atención que su patrocinada realizó al agraviado por hacer defecar a sus mascotas en la puerta de su casa en diferentes oportunidades.

\section{CUARTO: PRESUNCION DE INOCENCIA FRENTE AL TEMA PROBATORIO.}

4.1.- El Principio de Presunción de inocencia consagrado en el artículo $2^{\circ}$ inciso 24 literal "e" de nuestra Norma Fundamental, se configura, en tanto regla del juicio y desde la perspectiva constitucional, como el derecho a no ser condenado sin pruebas de cargo válidas, lo que implica 
que exista una mínima actividad probatoria realizada con las garantías necesarias, referidas a todos los elementos esenciales del delito y que de la misma se pueda inferir razonablemente los hechos y la participación del acusado en los mismos. 4.2.- Realizada la actividad probatoria, con todas las garantías procesales y sustanciales, este principio ha logrado ser enervado desde la tesis acusatoria, por las razones que a continuación se exponen.

\section{QUINTO: JUICIO SUBSUNCIÓN Y TIPICIDAD.}

5.1.-Habiéndose establecido como hechos probados, los cargos formulados - suceso histórico a la acusada Iris Sobeida Gonzáles Rubio; este Órgano Jurisdiccional, considera que la conducta de la acusada se subsume en la hipótesis normativa del artículo 206- $\mathrm{A}^{\circ}$ primer párrafo del Código Penal, por cuanto durante el juicio, se ha logrado determinar que el día veintisiete de Diciembre del dos mil diecinueve, la persona de Jorge Omar Díaz Uriarte, a las veinte con treinta horas, conjuntamente con su perrita Cielo, estuvieron en la calle San Luis del PP.JJ. San Antonio, lugar donde el can miccionó, y en circunstancias en que la persona de Jorge Omar Díaz Uriarte, llevaba a su perrita Cielo a su casa, la soltó para abrir la puerta, instantes en que la señora Yris Sobeida Gonzáles Rubio, arrojó una piedra de $5 \times 5 \mathrm{~cm}$ aproximadamente a la perrita, impactándole debajo de su ojo derecho, gritando de dolor, procediendo la persona de Jorge Omar Díaz Uriarte, inmediatamente a increparle su conducta a la señora Yris Sobeida Gonzáles Rubio, quien negó los hechos todo instantes, ingresando a su domicilio y no salir, pese que el agraviado le tocó la puerta, conduciendo el señor Jorge Omar Díaz Uriarte en compañía de su esposa Tatiana Hernández Tineo, a la perrita Cielo de emergencia a la Clínica Mister Can, ubicada en la Av. Libertad N 401- Urb. Santa Victoria, diagnosticándosele traumatismo ocular cerrado, causado por un cuerpo extraño, ocasionando hemorragia interna, inflamación alrededor del ojo, requiriendo tres días de atención con inyectables, analgésicos, antibióticas, además de gotas.

5.2.- Consecuentemente, expuestos así los hechos, no existe duda que estos se subsumen en el delito Contra el Patrimonio, modalidad Actos de Crueldad Contra Animales Domésticos, previsto y penado en el artículo 206- $\mathrm{A}^{\circ}$ primer párrafo del Código Penal.

\section{SEXTO: RAZONES QUE VINCULAN A LA ACUSADA CON LOS HECHOS MATERIA DE JUZGAMIENTO.}

6.1.- De acuerdo a los hechos probados, y subsunción de los hechos a la norma penal, a efectos de determinar la vinculación de la acusada Yris Sobeida Gonzáles Rubio, respecto a lo hechos materia de imputación, debe tenerse presente, que de la actuación probatoria, específicamente respecto de la presencia física de la acusada en el lugar de los hechos, está ha sido acreditado por todos los testigos en audiencia y por la propia acusada; existiendo controversia respecto que la acusada haya o no lanzado la piedra a la perrita Cielo; no obstante, dicho extremo ha sido determinado fehacientemente en juicio, habiendo acreditado que con la única persona que el agraviado Jorge Omar Díaz Uriarte tuvo un altercado con sus perritos, entre ellos la perrita cielo, fue con la acusada Yris Sobeida Gonzáles Rubio, ello ha sido corroborado con: - La testimonial de Sara Nelly Gonzales Rubio, quien ha señalado que el día veintisiete de diciembre del dos mil diecinueve, iba llegando del trabajo con su hermana Yris Sobeida Gonzáles Rubio, a las ocho y media de la noche, y encontraron al señor Omar con sus dos perritas, las cuales estaban haciendo sus necesidades, su hermana se acercó al señor Omar y le dice "señor, nuevamente usted haciendo orinar a sus perros, acaso no entiende”. - Testimonial de Shirley Luz Karina Castañeda Palomino, quien ha señalado: “... ese día vio que la señora Yris le comenzó a reclamar al señor Omar porqué sus perritos estaban defecando..." - Testimonial de Tatiana Loreti Hernández De Díaz, quien ha 
señalado “...su perrita llegó corriendo y vio que le cayó una piedra en su vista y se retorció de dolor, la perrita entró a la casa y en eso llegó su esposo, alzó a la perrita y vio que su perrita estaba ensangrentada, se soltó de los nervios al verla y recuerda haber visto a su vecino Marcos sentado en un muro de la iglesia y éste le dijo que fue la señora Yris quien tiró la piedra, en ese momento junto con su esposo fueron a su casa de la señora, tocaron la puerta duro y llorando porque estaba desesperada y nadie les abría". - Testimonial de José Marco Leyva Toro, quien ha señalado "...en diciembre del año dos mil diecinueve, a las ocho y media de la noche, llegó su vecino Omar y su vecina Tati en su carro, bajaron sus perritos y uno de ellos se escapó para el lado de la casa de la vecina Yris, el perrito se orinó en medio de la pista, en ese momento vino la señora Yris y la señora Sara, de lejos veía que la señora Yris estaba reclamando al señor Omar, el vecino regresaba con sus perritos a su casa, justo llegando a su casa le tiraron una piedra al perrito que le cayó en su ojo, a él le cayó en la pierna, su vecino Omar se fue a tocarle la puerta a reclamarle a la señor Yris porqué le pegó al perrito, su vecino al ver que no salía nadie se regresó y llevó a la clínica al perrito". - Acta de constatación policial de fecha veintisiete de diciembre del dos mil diecinueve, en la cual la propia acusada señala que el agraviado la sindica como la persona que ha maltratado su can. En conclusión; de las declaraciones vertidas en juicio tanto de cargo como descargo, se advierte que la única persona con quien el agraviado tuvo un altercado fue con la acusada por las perritas, entre ellos la perrita cielo. Asimismo, de todas las testimoniales no existe que una de ellas, haya hecho referencia alguna de persona extraña a la acusada, que haya ocasionado la lesión con la piedra a la perrita Cielo, existiendo tan sólo sindicación respecto de la acusada, quien discutió con el agraviado por las perritas. Lo expuesto se corrobora con la inferencia de la declaración de la acusada en sede fiscal, en el extremo que el agraviado regreso señalándole que le había tirado una piedra a su perrita.

6.2.- Por lo expuesto, habiéndose analizado lo desplegado en la actuación probatoria, este órgano jurisdiccional concluye, que se ha acreditado que el 17 accionar y vinculación de la acusada Yris Sobeida Gonzáles Rubio, en el presente juzgamiento, en calidad de AUTORA del delito Contra EI Patrimonio, modalidad ACTOS DE CRUELDAD CONTRA ANIMALES DOMESTICOS, ilícito previsto y penado en el artículo 206-A primer párrafo del Código Penal.

\section{SÉTIMO: RAZONES QUE DESVIRTÚAN LOS ARGUMENTOS DE LA DEFENSA.}

7.1.- Antes de dar respuesta a cada uno de los cuestionamientos formulados por el abogado de la defensa de la acusada, se debe de indicar lo siguiente. Que, el Tribunal Constitucional en la sentencia recaída en el Expediente $\mathrm{N}^{\circ}$ 1230-2002-HC/TC1, Caso César Humberto Tineo Cabrera), ha dejado establecido lo siguiente: "Que la Constitución no garantiza una determinada extensión de la motivación, por lo que su contenido esencial se respeta siempre y cuando exista fundamentación jurídica, congruencia entre lo pedido y lo resuelto y, por sí misma, exprese una suficiente justificación de la decisión adoptada, aún si ésta es breve o concisa, o se presenta el supuesto de motivación por remisión. Tampoco garantiza que, de manera pormenorizada, todas las alegaciones que las partes puedan formular dentro del proceso sean objeto de un pronunciamiento expreso y detallado".

7.2.- Respecto a lo alegado por la defensa en el extremo que la sindicación realizada por el agraviado a su patrocinada obedece al llamado de atención por sus perritas que le hiciera la acusada; se reitera que con la única persona con la que existió altercado entre el agraviado y la acusada por las perritas, fue con ésta, quien incluso admite que se molestó porque las perritas suelen orinarse cerca a su casa, infiriéndose que fue ésta la causante de la lesión proferida a la perrita Cielo, y ello se corrobora del acta de constatación fiscal, en el cual la acusada alude a la sindicación que le realiza el agraviado; limitándose la acusada a señalar que el agraviado le pateó la puerta de su 
vivienda, lo cual se condice con qué fue a reclamarle por la perrita y está no abría la puerta. No infiriéndose de lo actuado encono o sentimiento contrario entre el agraviado y la acusada, habiendo ésta última en razón de su enojo de ver a las perritas cerca a su casa actuado con la única intención de causarle daño a la perrita, ocasionándole así lesión en su ojo derecho, provocando hemorragia interna e inflamación del mismo.

7.3.- Respecto al único testigo de los hechos, el señor Marco Leyva Toro, en su declaración en sede fiscal dijo que no vio quien tiro la piedra, por lo que no se puede confiar en una persona que mintió ante el órgano jurisdiccional. Debe señalarse, que todos los testigos han sido contundentes en señalar el altercado entre el agraviado y la acusada por las perritas, no habiendo hecho referencia alguna de persona distinta a la acusada, lo que permite concluir que fue ésta la que provocó tal lesión.

7.4.- Respecto que la veterinaria señaló que la lesión de la perrita pudo haberse causada por un palo u objeto contundente, pero no mencionó en ningún momento que haya sido por una piedra, además de ello no mencionó el nombre de la perra que atendió, ni que ojo estaba lastimado por lo que 1 Sentencia del Tribunal Constitucional No 1230-2002-HC/TC, caso César Humberto Tineo Cabrera. F. J. 11.- debe ser valorado por el órgano jurisdiccional. En dicho extremo, se debe señalar que un objeto contundente, es cualquiera capaz de lesionar sin filo y punta, como es una piedra o un palo; se ha determinado que fue con una piedra, toda vez, que el testigo José Marco Leyva Toro desde su declaración en sede fiscal y en juicio, ha señalado que vio que fue una piedra, porque paso por su pierna.

7.5.- Con respecto a los gastos realizado por el agraviado, no fueron materia de contradictorio ya que no aparecían ni los números, nombres o de que se trataba, incluso pudo tratarse de otro animalito porque no se señala ni el día ni la hora en que fue atendido el perrito. Estos han sido materia del contradictorio, y ello se encuentra grabado en audio, es más para mayor nitidez de los mismos el representante del Ministerio Público compartió las que obran en carpeta fiscal. No obstante, debe precisarse que dicho extremo respecto a la atención recibida por la perrita Cielo, se encuentra corroborada con la testimonial de la médico Veterinaria y documento expedido por ésta.

\section{OCTAVO: ANALISIS DE ANTIJURIDICIDAD Y CULPABILIDAD}

8.1.- En el presente caso, no existen elementos que adviertan la existencia de causas de justificación, situación que tampoco ha sido invocada por las partes.

8.2.- Respecto a la culpabilidad, debe considerarse que los hechos han sido cometidos por persona en pleno uso de sus facultades mentales y con la clara posibilidad de realizar conducta distinta, por lo que, la culpabilidad de la acusada, debe darse por acreditada y aplicarle la consecuencia jurídica que corresponde, en consecuencia, al resultar el juicio de tipicidad positivo, corresponde amparar la pretensión punitiva postulada por el representante del Ministerio Público.

\section{NOVENO: DETERMINACION JUDICIAL DE LA PENA}

9.1.- Para efecto de determinarse la pena a imponer, debe tenerse en consideración el fin preventivo de la misma, tanto en su aspecto positivo general como especial. En el primer caso, con la finalidad de emitir un mensaje a la sociedad con respecto a la penalización de conductas como las que han sido objeto de juzgamiento, a fin que las personas no incurran en las mismas y entiendan que estas conductas, por su dañosidad y grave alteración de la paz social atacan las bases mismas 
de la sociedad y en segundo lugar, porque por la misma naturaleza de dichas conductas, los sujetos a quienes se les encuentra responsabilidad penal tienen que entender que la pena impuesta debe ser de una magnitud suficiente para que su reincorporación social no sea un mero formalismo, sino que sea producto de un acto de interiorización en el sentido que solo el respeto de la norma les garantizará una convivencia pacífica adecuada.

9.2.- Para ORE SOSA, el artículo 45-A del C.P., introdujo un sistema de individualización de la pena, que constituye un notable avance en la determinación del marco concreto de la pena-primer, segundo y tercer tercio-. Sus reglas procedimentales son claras: Se procede a dividir el marco penal abstracto del tipo penal en tres partes, así se obtiene: un tercio inferior, un tercio intermedio y un tercio superior (art. 45-A inc.1), luego para determinar en qué tercio se ha de individualizar la pena (pena concreta) se atiende a la concurrencia de las circunstancias de atenuación y agravación genéricas previstas en el artículo $46^{\circ}$ del C.P. Así no existen circunstancias atenuantes ni agravantes o concurren únicamente circunstancias atenuantes; la pena concreta se determinará dentro del tercio inferior. Cuando concurran circunstancias de agravación y de atenuación, la pena concreta se determina dentro del tercio intermedio. La pena se determinará dentro del tercio superior, cuando solo concurran circunstancias agravantes.

\section{3.- El delito Contra EI Patrimonio, modalidad ACTOS DE CRUELDAD CONTRA LOS ANIMALES} DOMESTICO, se encuentra regulado en el artículo 206- $\mathrm{A}^{\circ}$ del Código Penal, teniendo como pena conminada no menor de tres años, con cien a ciento ochenta días multa y con inhabilitación de conformidad con el numeral 13 del artículo $36^{\circ}$ del Código Penal. A lo antes señalado, el tipo penal de ACTOS DE CRUELDAD CONTRA ANIMALES DOMESTICOS, regula una pena de conformidad con el artículo $206-\mathrm{A}^{\circ}$ primer párrafo concordante con el artículo $29^{\circ}$ del Código Penal, no menor de dos días y no mayor de tres años, lo que vendría hacer la pena legal, que dividida en tercios sería, primer tercio de dos días a un año de pena privativa de la libertad, tercio intermedio de un año a dos años de pena privativa de la libertad, tercio superior de dos años hasta tres años de pena privativa de la libertad; corresponde determinar si existe atenuantes genéricas o agravantes genéricas o ambas a la vez para determinar el tercio que corresponde. En el caso en concreto, concurre atenuantes genéricas, y no concurren agravantes genéricas, correspondiendo determinar la pena concreta en el tercio inferior de la pena cominada para el delito, esto es, de DOS días a UN AÑO de pena privativa de la libertad, considerando adecuado haber solicitado el representante del Ministerio Público la pena de UN AÑO, al encontrarse dentro de la pena legal establecida. Respecto a la pena conjunta días multa, el representante del Ministerio Público ha solicitado CIEN días multa, pena que se encuentra dentro del tercio inferior respecto a la pena conminada, considerándolo el Órgano Jurisdiccional proporcional y razonable partir del tercio inferior de la pena legal establecida, esto es, CIEN DIAS MULTAS, que considerando en base a su remuneración mensual, sobre el veintinco por ciento del ingreso diario de la acusada de veinte soles, deberá pagar la suma de cinco soles diarios, equivalentes a un total de QUINIENTOS SOLES, que la acusada deberá 2 ORE SOSA, Eduardo. Determinación judicial de la pena, reincidencia y habilidad. Apropósito de las modificaciones operadores por la ley n. 30076. En Revista: Gaceta penal y procesal penal. Lima: gaceta jurídica editores. 20 cancelar a favor del Estado en el plazo de diez días, bajo apercibimiento de aplicarse el artículo $56^{\circ}$ del Código Penal, previo requerimiento judicial.

9.4.- Respecto a la pena de inhabilitación, pena conjunta en el caso en concreto, debe tenerse presente de conformidad con el artículo $38^{\circ}$ del Código Penal, la Inhabilitación Principal se extiende de seis meses a diez años, y teniendo en cuenta que la pena concreta determinada respecto a la acusada por el delito Contra el Patrimonio, modalidad ACTOS DE CRUELDAD CONTRAANIMALES DOMESTICOS es de UN AÑO, el Órgano Jurisdiccional considera que debe ser proporcional a la 
pena principal, y a los daños ocasionados, esto es, de UN AÑO, consistente en la Incapacidad para la tenencia de animales domésticos, de conformidad con el artículo $36^{\circ}$ numeral 13 ) del Código Penal.

9.5.- La exposición de motivos del Código Penal de 1991, ha establecido lo siguiente: "La Comisión revisora a pesar de reconocer la potencia criminógena de la prisión, considera que la pena privativa de libertad mantiene todavía su actualidad como respuesta para los delitos que son incuestionablemente graves. De esta premisa se desprende la urgencia de buscar otras medidas sancionadoras para ser aplicada a los delincuentes de poca peligrosidad o que no han cometido hechos graves que revisten mayor gravedad. Por otro lado, los elevados gastos que demandan la construcción y el sostenimiento de un centro penitenciario, obligan a imaginar nuevas formas de sanciones para los infractores que no amenacen significativamente la paz social y la seguridad colectivas. Es decir, el legislador ha previstos que las penas privativas de libertad efectivas se justifican únicamente para delitos de gran conmoción social, que no es el caso de autos.

9.6.- La reserva del fallo condenatorio es una pena sustitutoria a la pena privativa de libertad efectiva, por lo que corresponde analizar los presupuestos establecidos en el artículo $62^{\circ}$ del Código Penal, cuyo texto modificado por la Ley 30076, publicado en el Diario Oficial El Peruano el dieciséis de Agosto del dos mil trece, establece lo siguiente: "El juez puede disponer la reserva del fallo condenatorio siempre que de las circunstancias individuales, verificables al momento de la expedición de la sentencia, pueda colegir que el agente no cometerá nuevo delito. El pronóstico favorable sobre la conducta del sentenciado que formule la autoridad judicial requiere de debida motivación".

9.7.- El Recurso de Nulidad N³332-2004- Junín de fecha veintisiete de mayo del dos mil cinco, ha establecido como precedente vinculante lo siguiente: "La reserva del fallo condenatorio regulada en los artículos sesenta y dos a sesenta y siete del Código Penal, es importante precisar: a) Que esta es una medida alternativa a la pena privativa de libertad de carácter facultativo para el Juez, que se caracteriza fundamentalmente por reservar la imposición de la condena y el señalamiento de la pena concreta para el sentenciado culpable; b) Que, en consecuencia tal medida consiste declarar en la sentencia la culpabilidad del procesado, pero sin emitir la consiguiente condena y pena. Estos últimos extremos se reservan y se condicionan su extinción o pronunciamiento a la culminación exitosa o no de un periodo de prueba, dentro del cual el sentenciado deberá abstenerse de cometer nuevo delito y cumplir las reglas de conducta que le señale el juez; c] Que, la reserva 21 del fallo procede cuando concurren estos presupuestos: i] Que, el delito esté sancionado con pena conminada no superior a tres años de pena privativa de libertad o con multa; o con prestación de servicios a la comunidad o limitación de días libres que no excedan de noventa jornadas semanales; o con inhabilitación no superior a dos años; ii] Que, el juez en atención a las circunstancias del hecho y la personalidad del agente, emita un pronóstico favorable sobre la conducta futura del imputado; iii] Es de señalar que la reserva del fallo condenatorio también es aplicable en casos de pena conjunta o alternativas, siempre que tales sanciones se adecúen a los marcos cualitativos y cuantitativos antes mencionado".

9.8.- Con respecto a la primera exigencia, debe de considerarse que el delito materia de acusación es el delito de ACTOS DE CRUELDAD CONTRA ANIMALES DOMESTICOS, el cual se encuentra conminado con una pena cuyo extremo máximo no supera los tres años de pena privativa de la libertad, es decir, que no supera de ningún modo el máximo previsto por la norma, por lo que este extremo resulta positivo; en cuanto a la segunda exigencia, se tiene que el delito materia de juzgamiento, en cuanto a la pena concreta a imponer a la acusada, como se ha señalado es de UN 
AÑO, constituye agente primario, esto es, carece de antecedentes penales, lo que permite inferir que aquella no volverá cometer un nuevo delito, por lo que éste juzgado también considera que este extremo resulta positivo; en cuanto a la tercera exigencia, se ha indicado que la acusada, carece de antecedentes penales, es agente primario, por lo que no es reincidente ni habitual, conforme lo ha corroborado el Órgano Jurisdiccional; por lo que se puede hacer un pronóstico favorable de la conducta futura de la acusada.

9.9.- Finalmente la parte final del artículo $62^{\circ}$ del Código sustantivo, establece que el plazo de la reserva del fallo condenatorio es de uno a tres años. Teniendo en cuenta que se ha establecido que le corresponde a imponer a la acusada es de UN AÑO de pena privativa de la libertad; es razonable que el régimen de prueba sea de UN AÑO, tiempo suficiente para que en caso la acusada incumpla las reglas de conducta se pueda revocar el régimen de prueba y disponer su ingreso al Establecimiento Penal de Chiclayo; Ex Picsi, tanto más si este plazo representa al mínimo establecido por el legislador. -

\section{DECIMO: DETERMINACIÓN DE LA REPARACIÓN CIVIL.}

10.1.- En cuanto a la reparación civil, según el artículo $93^{\circ}$ del Código Penal, comprende tanto la restitución del bien o si no es posible, el pago de su valor y la indemnización de los daños y perjuicios.

10.2.- Respecto al monto de la reparación civil debe considerarse, que el fundamento de la responsabilidad civil, que origina la obligación de reparar, es la existencia de un daño civil causado por un ilícito penal, el que obviamente no puede identificarse como "ofensa penal" - lesión o puesta en peligro de un bien jurídico protegido, cuya base se encuentra en la culpabilidad del agente (la causa inmediata de la responsabilidad penal y la civil ex delito, infracción/daño, es distinta), el resultado dañoso y el objeto sobre el que recae la lesión son distintos 6 . Siendo así, la indemnización cumple una función reparadora, resarcitoria e indemnizatoria, de acuerdo a lo establecido por los artículos $92^{\circ}$ y $93^{\circ}$ del Código Penal, por lo que, el monto de la reparación civil debe guardar relación con el daño causado a los intereses de la víctima, debiendo comprender la restitución del bien afectado o siendo imposible esto, el pago de su valor y la indemnización por los daños y perjuicios.

10.3.- Así mismo, en el Acuerdo Plenario número 6-2006/CJ-1167, la Corte Suprema, estableció que el daño civil, debe entenderse como aquellos efectos negativos que derivan de la lesión de un interés protegido, lesión que puede originar tanto (1) daños patrimoniales, que consisten en la lesión de derechos de naturaleza económica, que debe ser reparada, radicada en la disminución de la esfera patrimonial del dañado y en el no incremento en el patrimonio del dañado o ganancia patrimonial neta dejada de percibir - menoscabo patrimonial-, cuanto (2) daños no patrimoniales, circunscritos a la lesión de derechos o legítimos intereses existenciales - no patrimoniales - tanto de las personas naturales como de las personas jurídicas - se afectan bienes inmateriales del perjudicado, que no tienen reflejo patrimonial alguno.

10.4.- Que, en el caso de autos, el Ministerio Público está solicitando se fije como monto de reparación civil la suma de SEISCIENTOS SOLES; no obstante, este Órgano Jurisdiccional considera atendiendo las boletas por medicamentos adquiridos ascendente a la suma de doscientos soles y estando al daño irrogado a la perrita Cielo, que un monto prudencial de acuerdo a los hechos suscitados debe ser la suma de TRESCIENTOS SOLES, monto que permitirá menguar en algo los daños ocasionados; máxime si durante el juzgamiento no se ha determinado con exactitud los gastos realizados. 
10.5.- De lo antes expuesto, se tiene que el monto por concepto de reparación Civil asciende a la suma de TRESCIENTOS SOLES, monto que deberá ser cancelado en ejecución de sentencia, no estableciéndose cuotas, en el entendido que dicho concepto es exigible desde que la sentencia queda firme.

DECIMO PRIMERO: IMPOSICIONDE COSTAS Teniendo en cuenta la declaración de culpabilidad que se está efectuando contra cada la acusada, de conformidad con lo dispuesto por el artículo $500^{\circ}$ numeral 1) del Código Procesal Penal, corresponde imponérsele el pago de las costas del proceso, las mismas que serán liquidadas en ejecución de sentencia, si las hubiere.

III.- PARTE RESOLUTIVA. Por los fundamentos expuestos, valorando las pruebas y juzgando los hechos según la sana crítica, en especial conforme a los principios de la lógica y en aplicación de los artículos citados y además los artículos IV del Título Preliminar, $12^{\circ}, 23^{\circ}, 29^{\circ}, 92^{\circ}, 93^{\circ}$, artículo 206- $\mathrm{A}^{\circ}$ primer párrafo del Código Penal, artículos $393^{\circ}$ a $399^{\circ}$, inciso 1 ), $402^{\circ}, 497^{\circ}$, inciso 1 del Código Procesal Penal, el Quinto Juzgado Penal Unipersonal de la Corte Superior de Justicia de Lambayeque, administrando justicia a nombre de la Nación,

FALLA: 3.1.- IMPONER RESERVA DEL FALLO CONDENATORIO a la acusada YRIS SOBEIDA GONZALES RUBIO, como AUTORA del delito Contra el Patrimonio, modalidad ACTOS DE CRUELDAD CONTRA ANIMALES DOMESTICOS, ilícito previsto y penado en el artículo 206-A primer párrafo del Código Penal, en agravio de JORGE OMAR DÍAZ URIARTE, por el REGIMEN DE PRUEBA DE UN AÑO, quedando sujeto a observar las siguientes reglas de conducta:

2) Prohibición de ausentarse del lugar donde reside sin autorización del juez;

3) Comparecer mensualmente al Juzgado personal y obligatoriamente para informar y justificar sus actividades, la cual mientras exista las restricciones por razones sanitarias será en forma virtual y al termino de ésta de hacerlo en forma presencial dentro de los siete primeros días,

4) Reparar los daños ocasionados con el delito, consistente en el pago de la reparación civil impuesta en la suma de TRESCIENTOS SOLES, concepto que deberá ser cancelado en ejecución de sentencia; bajo apercibimiento de aplicársele el artículo $65^{\circ}$ inciso 3) del Código Penal, esto es, de recovársele el régimen de prueba, imponiéndosele la pena de UN AÑO de pena privativa de la libertad, CIEN DÍAS MULTA, equivalente a la suma de QUINIENTOS SOLES, bajo apercibimiento de ley e INHABILITACIÓN, consistente en la INCAPACIDAD para la tenencia de animales domésticos de conformidad con el artículo $36^{\circ}$ numeral 13) del Código Penal, por el lapso de tiempo de UN AÑO.

3.2.- FIJO por concepto de REPARACIÓN CIVIL la suma de TRESCIENTOS SOLES, a favor de la parte agraviada JORGE OMAR DÍAZ URIARTE, concepto que deberá ser cancelado en ejecución de sentencia.

3.3.- SE IMPONE pago de COSTAS a la sentenciada, las que deberán ser liquidadas en ejecución de sentencia si las hubiera.

3.4.- FIRME o EJECUTORIADA que sea la presente sentencia debe darse cumplimiento en sus propios términos; EXPIDIÉNDOSE los testimonios y boletines de condena. En su oportunidad ARCHIVESE el presente donde corresponda. TOMESE RAZÓN Y HÁGASE SABER. - 


\section{CONCLUSIONES}

1. La expresión animal es amplia, es decir, comprende a todas las especies de animales que existen, a la gran cantidad de diversidad de animales. Abarca a los invertebrados como a los vertebrados

2. Los animales para el Derecho son bienes muebles, sin embargo, nivel mundial, la regulación de los animales, viene transformándose. Existe la tendencia mundial a la des cosificarlos, es decir, a ya no considerarlos como simples bienes muebles.

3. Sin embargo, a pesar de ello, nuestro ordenamiento no ha sido ajeno en algún sentido en considerar a los animales como seres sensibles, pues, desde la promulgación de la Ley 30407 (enero del año 2016) se prescribe textualmente que los animales tienen condición de seres sensibles. Está ley, solo se refiere a los animales vertebrados domésticos y silvestres mantenidos de cautiverios.

4. Teniendo en cuenta la tendencia actual de la descosificación de los animales, que estos son merecedores de buen trato y que no se les debe maltratar ni causar actos de crueldad, se podría considerar que el bien protegido es el animal mismo, pues, el interés que se quiere salvaguardar es la vida, integridad y buen trato hacia los animales.

5. La redacción de la segunda parte del artículo 206 A debe ser redactado de una mejor manera. Es decir, este extremo debe diferenciar y precisar a quién se aplica: i) a los domésticos, salvo que sea para fines de consumo humano (en cuyo supuesto no se aplicaría, más abajo se explica), salvo, que la finalidad de la norma haya sido que ningún peruano consuma ningún tipo de animal doméstico, ii) expresamente se precise a los de compañía y, iii) a los animales silvestres

6. El sujeto activo de este delito puede ser cualquier persona que realice actos de crueldad contra estos animales.

7. Respecto al sujeto pasivo del delito no existe uniformidad de criterios. Si el sujeto pasivo de todo delito es el titular del bien jurídico protegido, sería, necesario que previamente se precise cuál es el bien jurídico protegido en este delito. Dependiendo de la posición que uno asuma, respecto al bien jurídico protegido, se podrá determinar quién es el sujeto pasivo de este delito.

8. Corresponderá a la ley y a la doctrina respectiva, precisar cuál es el bien jurídico y cuál es el sujeto pasivo de estos delitos. Falta mucho por definir y precisar.

\section{REFERENCIAS}

- Arana García, E. (2006). Animales de compañía y administración local. Revista Derecho del Medio Ambiente y Administración Local.

- Biología (2011) Fondo Editorial de la Universidad Nacional Mayor de San Marcos. 4ta edición.

- De Martín-Pinillos, M. (2018) Aspectos fundamentales del delito de maltrato animal (artículo 337 CP) Universidad de la Laguna. 
- García, Enrique A. (2018) El bienestar de los animales como seres sensibles-sintientes: su valor como principio general, de rango constitucional, en el derecho español. La LeyDigital s/n

- Giménez-Candela, Marita; Cersosimo, Raffaela. (2021). La enseñanza del derecho animal. Valencia: Tirant Blanc.

- Helena Curtis y Adriana Schnek. (2008). Curtis. Biología (Sétima Edición en Español ed.). Ed. Médica Panamericana.

- Jaurrieta Ortega, Ignacio (2019) El bien jurídico protegido en el delito de maltrato animal UNED. Revista de Derecho UNED, núm. 24, 2019

- Jiménez de Asúa , L. (1965). Tratado de Derecho Penal (Vol. III). Losada.

- Prats, Elena. (2020, p. 12) El delito de Maltrato Animal en España: Pasado, Presente y Futuro. P. 12

- Claus, Roxin (1977) Derecho Penal - Parte General. Tomo I. Fundamentos de la estructura de la teoría del delito. Civitas. p. 70

- Serrano Tárraga, Dolores. (2004) El maltrato de animales. Revista de Derecho Penal y Criminología 2. ${ }^{a}$ Época, $n .^{\circ}$ extraordinario 2

Fecha de recepción: 26 de octubre de 2021

Fecha de aceptación: 22 de noviembre de 2021 